\title{
Revisiting the Implications of Positive Germline Testing Results Using Multi-gene Panels in Breast Cancer Patients
}

\author{
GEORGIOS N. TSAOUSIS ${ }^{1}$, EIRINI PAPADOPOULOU ${ }^{1}$, KONSTANTINOS AGIANNITOPOULOS $^{1}$, \\ GEORGIA PEPE ${ }^{1}$, NIKOLAOS TSOULOS ${ }^{1}$, IOANNIS BOUKOVINAS ${ }^{2}$, THEOFANIS FLOROS ${ }^{3}$, \\ RODONIKI IOSIFIDOU ${ }^{2}$, OURANIA KATOPODI ${ }^{4}$, ANNA KOUMARIANOU ${ }^{5}$, CHRISTOS MARKOPOULOS $^{6}$, \\ KONSTANTINOS PAPAZISIS ${ }^{7}$, VASILEIOS VENIZELOS ${ }^{8}$, ACHILLEAS KAPSIMALIS $^{9}$, \\ GRIGORIOS XEPAPADAKIS ${ }^{10}$, AMANDA PSYRRI ${ }^{11}$, EUGENIU BANU $^{12}$, DAN TUDOR ENIU ${ }^{13}$, \\ ALEXANDRU BLIDARU ${ }^{14}$, DANA LUCIA STANCULEANU ${ }^{15}$, ANDREI UNGUREANU ${ }^{16}$, VAHIT OZMEN ${ }^{17}$, \\ SUALP TANSAN $^{18}$, MEHMET TEKINEL ${ }^{19}$, SUAYIB YALCIN ${ }^{20}$ and GEORGE NASIOULAS ${ }^{1}$ \\ ${ }^{1}$ Genekor Medical S.A., Athens, Greece; \\ ${ }^{2}$ Bioclinic Thessaloniki, Thessaloniki, Greece; \\ ${ }^{3}$ Oncology Department, Athens Naval and Veterans Hospital, Athens, Greece; \\ ${ }^{4}$ Euroclinic Group, Athens, Greece; \\ ${ }^{5}$ Attikon University Hospital, National and Kapodistrian University of Athens, Medical School, Athens, Greece; \\ ${ }^{6}$ Medical School, National and Kapodistrian University of Athens, Athens, Greece; \\ ${ }^{7}$ Euromedica General Clinic of Thessaloniki, Thessaloniki, Greece; \\ ${ }^{8}$ Breast Unit, Metropolitan Hospital, Piraeus, Greece; \\ ${ }^{9}$ General Surgeon, Drama, Greece; \\ ${ }^{10}$ IASO, General Maternity and Gynecology Clinic, Athens, Greece; \\ ${ }^{11}$ Department of Internal Medicine, Section of Medical Oncology, \\ National and Kapodistrian University of Athens, Attikon University Hospital, Athens, Greece; \\ ${ }^{12}$ Spitalul Sfantul Constantin Brasov, Brasov, Romania; \\ ${ }^{13}$ Department of Surgery II, Iuliu Hațieganu University of Medicine and Pharmacy, Cluj-Napoca, Romania; \\ ${ }^{14}$ Department of Surgical Oncology, Oncological Institute "Al. Trestioneanu" of Bucharest, \\ University of Medicine and Pharmacy Carol Davila, Bucharest, Romania; \\ ${ }^{15}$ Department of Oncology, Faculty of General Medicine, \\ "Carol Davila" University of Medicine and Pharmacy, Bucharest, Romania; \\ ${ }^{16}$ Amethyst Radiotherapy Cluj-Napoca, Cluj-Napoca, Romania; \\ ${ }^{17}$ Department of General Surgery, Istanbul University, Istanbul Faculty of Medicine, Istanbul, Turkey; \\ ${ }^{18}$ Tansan Oncology, Istanbul, Turkey; \\ ${ }^{19}$ Private Practice, Fulya Sisli, Turkey; \\ ${ }^{20}$ Department of Medical Oncology, Hacettepe University Cancer Institute, Ankara, Turkey
}

\begin{abstract}
Background/Aim: The use of multi-gene panels for germline testing in breast cancer enables the estimation of cancer risk and guides risk-reducing management options.
\end{abstract}

This article is freely accessible online.

Correspondence to: Georgios Tsaousis, Ph.D., Genekor Medical S.A, 52 Spaton Ave, Gerakas 15344, Athens, Greece. Tel: +30 2106032138,e-mail: gtsaousis@genekor.com

Key Words: Germline testing, NGS, breast cancer, genetic counselling, risk assessment.
The aim of this study was to present data that demonstrate the different levels of actionability for multi-gene panels used in genetic testing of breast cancer patients and their family members. Materials and Methods: We performed an analysis in our clinical database to identify breast cancer patients undergoing genetic testing. We reviewed positive results in respect of risk estimation and management, cascade family testing, secondary findings and information for treatment decision-making. Results: A total of 415 positive test reports were identified with $57.1 \%, 18.1 \%, 10.8 \%$ and $13.5 \%$ of individuals having pathogenic/likely pathogenic variants in high, moderate, low and with insufficient evidence for breast cancer risk genes, respectively. Six point seven percent of 
individuals were double heterozygotes. Conclusion: Germline findings in $92 \%$ of individuals are linked to evidence-based treatment information and risk estimates for predisposition to breast and/or other cancer types. The use of germline findings for treatment decision making expands the indication of genetic testing to include individuals that could benefit from targeted treatments.

During the last two decades, genetic testing for breast cancer susceptibility has evolved to an integral part of medical practice (1). In the early years of genetic testing, only $B R C A 1 / 2$ genes were analyzed for pathogenic variants to investigate heredity in breast cancer patients and members of their families. Additional predisposition genes, that are associated with different levels of breast cancer risk, have been characterized and account for approximately 50\% of pathogenic variants identified $(2,3)$. The advent of the next generation sequencing (NGS) technology allowed the incorporation of these genes in breast cancer testing through the development of multi-gene panels (4-6). Sequencing has been made affordable for more patients and this resulted in an expansion of genetic data that facilitates the study of hereditary breast cancer and expands the clinical utility of genetic tests. New data provide important feedback/evidence for the use and translation of additional high, moderate, and low penetrance genes in routine clinical testing for breast cancer. This is evident in the recent versions of the National Comprehensive Cancer Network (NCCN) Genetic/Familial High-Risk Assessment guidelines for breast, ovarian, and pancreatic cancer that have been updated to incorporate the emerging information of newer added cancer susceptibility genes and to expand testing criteria for BRCAl/2 genes to "Testing Criteria for High-Penetrance Breast and/or Ovarian Cancer Susceptibility Genes" (7).

Multi gene testing, although cost-effective, introduces some challenges to the use of the results for decision making in clinical practice. For some genes there is limited data and therefore not clear guidelines for risk determination and management (8). Secondary findings that give information about the predisposition for other common cancer types discover individuals with increased genetic risk for cancer and consequently add to the actionability of multi-gene panels (9).

Advances in the landscape of breast and ovarian cancer treatment mainly through the development, use and drug approvals of poly (ADP-ribose) polymerase inhibitors (PARPi) has added the potential to use germline testing results as a predictive biomarker. Moreover, the correlation of defects in mismatch repair (MMR) genes with microsatellite instability (MSI) enables the use of germline findings in these genes as predictors of the efficacy of cancer immunotherapy using immune checkpoint inhibitors (ICIs) $(10,11)$. This has expanded the clinical indication of germline testing from the identification of high-risk individuals, where it is likely to impact the risk management, to individuals who could also get actionable information for systemic therapy decision making (7).

Interestingly, the accumulated data, show patients with mutations in more than one gene (double heterozygotes) that remain to be interpreted for their association with clinical risk and the potential therapeutic use (12). Today, genetic reports have changed to incorporate cancer risk calculations through the development of statistical models and tools that take into account personal and family history information (13). Subsequently, test reports act as genetic counseling resources for patients and healthcare professionals.

Here we present data that support the different levels of actionability for multi-gene panels. We describe and discuss the emerging features of genetic testing and reporting in breast cancer based on our data. Furthermore, selected cases outline that the evolution in cancer susceptibility genetic testing has created an increased demand for clarity in clinical reporting and communication of genetic tests and their implications.

\section{Materials and Methods}

Study group. We conducted a retrospective analysis of individuals referred for germline genetic testing using a multi-gene NGS panel in Genekor Medical SA, Athens, Greece. We used our clinical database to select referrals of breast cancer patients or healthy individuals that undertook cancer susceptibility genetic testing due to family history of breast cancer. Positive reports with pathogenic (P)/likely pathogenic (LP) variants and/or large genomic rearrangements were further analyzed. Prior to genetic testing all individuals had provided informed consent and permission for the anonymous use of their data for research purposes and/or scientific publications. Information on demographics, clinical history, and family history of cancer was collected from test requisition forms, and pedigrees that had been provided by the ordering clinicians at the time of testing in our data archive. No other clinical information was available at the time of testing or was accessible retrospectively concerning the management and outcomes of tested patients.

All selected individuals had been referred for germline genetic testing using a multi-gene NGS panel as described in our previous study (14). Detailed information on DNA extraction, NGS library preparation and sequencing is available in the same study (14). In brief, genomic DNA was extracted from the sample under investigation and was analyzed by an Amplicon-based 26 gene panel protocol (Multiplicom NV, Agilent, Santa Clara, CA, USA) or a solution based capture approach using a custom target enrichment panel containing 36 genes (SeqCap EZ Choice, NimbleGen, Roche, Pleasanton, CA, USA). Sequencing was carried out using Illumina technology. Reads were aligned to the reference sequence (GRCh37), and sequence changes were identified and interpreted in the context of a single clinically relevant transcript. All clinically significant observations were confirmed by Sanger Sequencing. All targeted regions within exons were sequenced with an average read coverage of $900 \times$ and a minimum depth of $>20 \times$ for $99.9 \%$ of bases.

The study was approved by the ethics committee of Hellenic Breast Surgeons Society. 
Risk calculation and gene classification. Genes were further classified as high, moderate, low, and unknown penetrance genes based on their relative risk for breast cancer development that they confer to pathogenic variant carriers as previously described $(7,14,15)$ and the strength of the available evidence (Table I). High-risk genes are considered those which when mutated, confer a high relative risk of cancer development; greater than four times $(>4 \times)$ the absolute lifetime risk of the general population. Pathogenic/likely pathogenic variants in moderate-risk genes confer a two to four times (2-4x) risk of cancer development compared to the general population. Low-risk genes are those related to less than two times $(<2 \times)$ risk of cancer. Some genes have limited or yet insufficient evidence available concerning their association with cancer and the magnitude of the cancer risk. This classification is constantly evolving in reflection to the accumulated clinical evidence from different clinical resources towards a universal scientific agreement (16).

Risk calculations for breast cancer and other cancer types associated with genes of the selected examples were performed using the risk prediction clinical decision support tool ASK2ME (All Syndromes Known to Man Evaluator) (17).

The pedigrees of the families in the selected examples were designed following the established recommendations and the standardized human pedigree nomenclature (18).

Statistical analysis. Statistics were performed with $\mathrm{R}$ (version 3.5.3). The $p$-values were based on Fisher's exact test. A $p$-value $<0.05$ was considered statistically significant.

\section{Results}

We reviewed a total of 2,117 cases referred for genetic testing due to personal or family history of breast cancer (Table II). In $844 / 2,117$ (39.9\%) of cases no pathogenic or likely pathogenic variants were detected and received a negative report. Variants of Uncertain Significance (VUS) were detected in 858/2117 (40.5\%) of tested individuals and subsequently received a VUS report, adding to genetic testing results that are not used to alter the medical management of unaffected individuals and patients.

In a total of $415(19.6 \%)$ cases a P or LP variant was identified in a breast cancer patient or an unaffected individual with family history of breast cancer. P and LP variants were identified in 24 out of the 36 genes tested. Reports with positive findings were grouped according to the associated breast cancer risk of the gene in the following subgroups: genes with a high, moderate, low or unknown (insufficient evidence) risk for breast cancer as described in Methods (Figure 1). Moreover, a special category of positive findings were cases where two P/LP variants were detected in two different genes or the same gene (double heterozygotes). Out of the 415 individuals, 391 (94.2\%) had a personal history of breast cancer, and the remaining 24 individuals were unaffected with at least one first degree relative with personal history of breast cancer. Average age of diagnosis and testing were 44 and 46 years old, respectively.
High-risk genes for breast cancer. A P/LP variant in a highrisk breast cancer gene was identified in 238/415 (57.3\%) of the positive cases and specifically in BRCAl (136/415, $32.8 \%)$, BRCA2 (69/415, 16.6\%), PALB2 (24/415, 5.8\%), PTEN (2/415, 0.5\%), and TP53 (7/415, 1.7\%). P/LP variants in BRCA1/2 genes account for $49.4 \%$ (205/415) of positive findings and $86.5 \%(205 / 238)$ of positive findings in highrisk breast cancer genes.

Moderate-risk genes for breast cancer. A P/LP variant in a moderate-risk for breast cancer gene was identified in 68/415 (16.4\%) of the positive cases and specifically in CHEK2 $(37 / 415,8.9 \%)$ and ATM $(27 / 415,6.5 \%)$. The moderate-risk pathogenic variant c.657del5 (p.Lys219Asnfs*16) in $N B N$ was identified in $1.7 \%(7 / 415)$ of positive cases.

Low-risk genes for breast cancer. A P/LP variant in a low-risk for breast cancer gene was identified in 53/415 (12.8\%) of positive cases. The majority of cases $(56.6 \%, 30 / 53)$ carried the low penetrance c.470T $>\mathrm{C}$ (p.Ile157Thr) pathogenic variant in CHEK2. The remaining cases had P/LP variants in BARD1, BRIP1, MLH1, MSH2, MSH6, NF1 and RAD51C.

Genes with insufficient evidence for breast cancer risk. In 56 of $415(13.5 \%)$ positive results, tested individuals carried a mutation in a gene whose association with breast cancer risk is supported by limited or insufficient evidence (FANCA, FANCM, NBN, MRE11, PMS2, RAD50, RAD51B, XRCC2, $M U T Y H)$. The majority of the cases in this category were MUTYH heterozygotes (monoallelic) $(42.9 \%, 24 / 56)$ and RAD50 pathogenic variant carriers $(28.6 \%, 16 / 56)$.

Double heterozygotes. In 30/415 (7.2\%) of the positive cases, a $\mathrm{P} / \mathrm{LP}$ variant was identified in two different genes (double heterozygotes). The majority of double heterozygotes (16/30, $53.3 \%$ ) carried a variant in the CHEK2 gene, with the low penetrance c.470T $>C$ (p.Ile157Thr) pathogenic variant being the most common alteration found in this category $(8 / 30$, $26.7 \%)$. In $20 \%$ of cases (6/30) the second P/LP alteration was a heterozygous variant in $M U T Y H$ (MUTYH monoallelic). Other genes with pathogenic alterations in double heterozygotes were ATM, BRCA1, BRCA2, BLM, BRIP1, ABRAXAS1, NBN, FANCA, FANCM, MSH6, PALB2, PMS2, RAD50 and RAD51C. Detailed information is included in Figure 2.

Large genomic rearrangements (LGRs). Notably, in 36/415 $(8.7 \%)$ of individuals a large genomic rearrangement, referring to the deletion of one or more exons of a gene, was detected. Of the 36 LGRs detected, 21 occurred in BRCA1, 7 in CHEK2, 3 in PMS2, 2 in FANCA, and 1 in each of the $A T M, B R C A 2$ and $M S H 2$ genes. In 4 cases (2 with $C H E K 2$, 1 with FANCA and 1 with $P M S 2$ ) the individual carried a second P/LP variant (double heterozygote). 
Table I. Clinical utility and different levels of information associated with pathogenic/likely pahtogenic variants in genes tested positive in our cohort.

\begin{tabular}{|c|c|c|c|c|c|c|c|c|c|c|}
\hline \multirow[b]{2}{*}{ Gene } & \multicolumn{4}{|c|}{ Breast cancer risk } & \multicolumn{4}{|c|}{ Other cancer risk } & \multicolumn{2}{|c|}{ Treatment actionability } \\
\hline & Cases & Risk & Evidence & Management & Type & Risk & Evidence & Management & Category & y Evidence \\
\hline \multirow[t]{4}{*}{$B R C A 1$} & 136 & High $(>60 \%)$ & Very strong & RRS, Surveillance & & & & & PARPi & Approved \\
\hline & & & & & Ovarian & High (>39-58\%) & Very strong & RRS, Surveillance & PARPi & Approved \\
\hline & & & & & Pancreatic & Moderate $(<5 \%)$ & Strong & Surveillance & PARPi & Approved \\
\hline & & & & & Prostate & Increased & Limited & Surveillance & PARPi & Approved \\
\hline \multirow[t]{5}{*}{$B R C A 2$} & 69 & High $(>60 \%)$ & Very strong & RRS, Surveillance & & & & & PARPi & Approved \\
\hline & & & & & Ovarian & High $(>39-58 \%)$ & Very strong & RRS, Surveillance & PARPi & Approved \\
\hline & & & & & Pancreatic & Moderate $(5-10 \%)$ & Strong & Surveillance & PARPi & Approved \\
\hline & & & & & Prostate & Low & Strong & Surveillance & PARPi & Approved \\
\hline & & & & & Melanoma & Increased & Limited & Surveillance & PARPi & $\begin{array}{c}\text { Off label/ } \\
\text { Clinical trials }\end{array}$ \\
\hline \multirow[t]{3}{*}{ PALB2 } & 24 & High $(41-60 \%)$ & Strong & RRS, Surveillance & & & & & PARPi & $\begin{array}{l}\text { Off label/ } \\
\text { Clinical trials }\end{array}$ \\
\hline & & & & & Ovarian & Increased (3-5\%) & Strong & RRS, Surveillance & PARPi & $\begin{array}{c}\text { Off label/ } \\
\text { Clinical trials }\end{array}$ \\
\hline & & & & & Pancreatic & Moderate $(5-10 \%)$ & Limited & Surveillance & PARPi & $\begin{array}{c}\text { Off label/ } \\
\text { Clinical trials }\end{array}$ \\
\hline \multirow[t]{6}{*}{ PTEN } & 2 & High $(>60 \%)$ & Strong & RRS, Surveillance & & & & & - & - \\
\hline & & & & & Colorectal & Increased & Strong & Surveillance & - & - \\
\hline & & & & & Endometrial & High (19-28\%) & Strong & RRS, Surveillance & - & - \\
\hline & & & & & Melanoma & Increased & Limited & Surveillance & - & - \\
\hline & & & & & Renal cell & Increased & Limited & Surveillance & - & - \\
\hline & & & & & Thyroid & Increased & Limited & Surveillance & - & - \\
\hline \multirow[t]{6}{*}{ TP53 } & 7 & High $(>60 \%)$ & Strong & RRS, Surveillance & & & & & - & - \\
\hline & & & & & Pancreatic & Moderate $(5-10 \%)$ & Limited & Surveillance & - & - \\
\hline & & & & & Colorectal & Increased & Strong & Surveillance & - & - \\
\hline & & & & & Melanoma & Increased & Limited & Surveillance & - & - \\
\hline & & & & & Brain & Increased & Limited & Surveillance & - & - \\
\hline & & & & & Multiple & Increased & Limited & Surveillance & - & - \\
\hline \multirow[t]{6}{*}{ ATM } & 27 & $\begin{array}{l}\text { Moderate } \\
(15-40 \%)\end{array}$ & Strong & Surveillance & & & & & PARPi & $\begin{array}{c}\text { Off label/ } \\
\text { Clinical trials }\end{array}$ \\
\hline & & & & & Ovarian & Low $(<3 \%)$ & Strong & Surveillance & PARPi & $\begin{array}{c}\text { Off label/ } \\
\text { Clinical trials }\end{array}$ \\
\hline & & & & & Pancreatic & Moderate $(5-10 \%)$ & Strong & Surveillance & PARPi & $\begin{array}{c}\text { Off label/ } \\
\text { Clinical trials }\end{array}$ \\
\hline & & & & & Prostate & Unknown & Insufficient & - & PARPi & Approved \\
\hline & & & & & Colorectal & Unknown & Limited & - & PARPi & Off label/ \\
\hline & & & & & & & & & & Clinical trials \\
\hline \multirow[t]{4}{*}{ CHEK2* } & 39 & $\begin{array}{l}\text { Moderate } \\
(15-40 \%)\end{array}$ & Strong & Surveillance & & & & & PARPi & $\begin{array}{c}\text { Off label/ } \\
\text { Clinical trials }\end{array}$ \\
\hline & & & & & Colorectal & Increased & Limited & Surveillance & PARPi & $\begin{array}{c}\text { Off label/ } \\
\text { Clinical trials }\end{array}$ \\
\hline & & & & & Ovarian & Unknown & Insufficient & - & PARPi & $\begin{array}{c}\text { Off label/ } \\
\text { Clinical trials }\end{array}$ \\
\hline & & & & & Prostate & Increased & Limited & - & PARPi & Approved \\
\hline \multirow[t]{3}{*}{$N B N^{* *}$} & 7 & Moderate & Limited & Based on FH & & & & & PARPi & Clinical trials \\
\hline & & & & & Ovarian & Unknown & Insufficient & - & PARPi & Clinical trials \\
\hline & & & & & Prostate & Increased & Limited & - & PARPi & $\begin{array}{c}\text { Off label/ } \\
\text { Clinical trials }\end{array}$ \\
\hline \multirow[t]{2}{*}{$B A R D 1$} & 7 & Low & Limited & Surveillance & & & & & PARPi & $\begin{array}{c}\text { Off label/ } \\
\text { Clinical trials }\end{array}$ \\
\hline & & & & & Ovarian & $\begin{array}{c}\text { Potentially } \\
\text { increased }\end{array}$ & Limited & - & PARPi & $\begin{array}{c}\text { Off label/ } \\
\text { Clinical trials }\end{array}$ \\
\hline \multirow[t]{2}{*}{ BRIP1 } & 7 & Low & Limited & Based on FH & & & & & PARPi & $\begin{array}{c}\text { Off label/ } \\
\text { Clinical trials }\end{array}$ \\
\hline & & & & & Ovarian & High $(>10 \%)$ & Strong & RRS, Surveillance & PARPi & $\begin{array}{c}\text { Off label/ } \\
\text { Clinical trials }\end{array}$ \\
\hline
\end{tabular}


Table I. Continued

\begin{tabular}{|c|c|c|c|c|c|c|c|c|c|c|}
\hline \multirow[b]{2}{*}{ Gene } & \multicolumn{4}{|c|}{ Breast cancer risk } & \multicolumn{4}{|c|}{ Other cancer risk } & \multicolumn{2}{|c|}{ Treatment actionability } \\
\hline & Cases & Risk & Evidence & Management & Type & Risk & Evidence & Management & Category & y Evidence \\
\hline & & & & & Prostate & $\begin{array}{c}\text { Potentially } \\
\text { increased }\end{array}$ & Limited & - & PARPi & Approved \\
\hline \multirow[t]{7}{*}{$M L H 1$} & 1 & Low $(<15 \%)$ & Limited & Based on $\mathrm{FH}$ & & & & & ICI & $\begin{array}{c}\text { Well- } \\
\text { powered } \\
\text { studies }\end{array}$ \\
\hline & & & & & Ovarian & High (4-20\%) & Strong & RRS, Surveillance & ICI & $\begin{array}{c}\text { Well- } \\
\text { powered } \\
\text { studies }\end{array}$ \\
\hline & & & & & Colorectal & High (46-61\%) & Strong & Surveillance & ICI & $\begin{array}{c}\text { Well-powered } \\
\text { studies }\end{array}$ \\
\hline & & & & & Endometrial & High (34-54\%) & Strong & RRS, Surveillance & ICI & $\begin{array}{c}\text { Well-powered } \\
\text { studies }\end{array}$ \\
\hline & & & & & Gastric & High $(5-7 \%)$ & Strong & Surveillance & ICI & $\begin{array}{c}\text { Well-powered } \\
\text { studies }\end{array}$ \\
\hline & & & & & Pancreatic & Low $(5 \%)$ & Limited & Surveillance & ICI & $\begin{array}{c}\text { Well-powered } \\
\text { studies }\end{array}$ \\
\hline & & & & & Prostate & Low $(4-12 \%)$ & Limited & - & ICI & $\begin{array}{c}\text { Well-powered } \\
\text { studies }\end{array}$ \\
\hline \multirow[t]{7}{*}{$\mathrm{MSH} 2$} & 1 & Low $(<15 \%)$ & Limited & Based on FH & & & & & ICI & $\begin{array}{c}\text { Well-powered } \\
\text { studies }\end{array}$ \\
\hline & & & & & Ovarian & High $(>10 \%)$ & Strong & RRS, Surveillance & ICI & $\begin{array}{c}\text { Well-powered } \\
\text { studies }\end{array}$ \\
\hline & & & & & Colorectal & High (33-52\%) & Strong & Surveillance & ICI & $\begin{array}{c}\text { Well-powered } \\
\text { studies }\end{array}$ \\
\hline & & & & & Endometrial & High (21-57\%) & Strong & RRS, Surveillance & ICI & $\begin{array}{c}\text { Well-powered } \\
\text { studies }\end{array}$ \\
\hline & & & & & Gastric & High $(<9 \% \%)$ & Strong & Surveillance & ICI & $\begin{array}{c}\text { Well-powered } \\
\text { studies }\end{array}$ \\
\hline & & & & & Pancreatic & Low $(1-2 \%)$ & Limited & Surveillance & ICI & $\begin{array}{c}\text { Well-powered } \\
\text { studies }\end{array}$ \\
\hline & & & & & Prostate & Low $(4-16 \%)$ & Limited & - & ICI & $\begin{array}{c}\text { Well-powered } \\
\text { studies }\end{array}$ \\
\hline \multirow[t]{7}{*}{ MSH6 } & 3 & Low $(<15 \%)$ & Limited & Based on $\mathrm{FH}$ & & & & & ICI & $\begin{array}{c}\text { Well-powered } \\
\text { studies }\end{array}$ \\
\hline & & & & & Ovarian & High $(>10 \%)$ & Strong & RRS, Surveillance & ICI & $\begin{array}{c}\text { Well-powered } \\
\text { studies }\end{array}$ \\
\hline & & & & & Colorectal & High (10-44\%) & Strong & Surveillance & ICI & $\begin{array}{c}\text { Well-powered } \\
\text { studies }\end{array}$ \\
\hline & & & & & Endometrial & High (16-49\%) & Strong & RRS, Surveillance & ICI & $\begin{array}{c}\text { Well-powered } \\
\text { studies }\end{array}$ \\
\hline & & & & & Gastric & High (1-8\%) & Strong & Surveillance & ICI & $\begin{array}{c}\text { Well-powered } \\
\text { studies }\end{array}$ \\
\hline & & & & & Pancreatic & Low $(1-2 \%)$ & Limited & Surveillance & ICI & $\begin{array}{c}\text { Well-powered } \\
\text { studies }\end{array}$ \\
\hline & & & & & Prostate & Low $(3-12 \%)$ & Limited & - & ICI & $\begin{array}{c}\text { Well-powered } \\
\text { studies }\end{array}$ \\
\hline \multirow[t]{2}{*}{$N F 1$} & 2 & Low $(15-40 \%)$ & Strong & Surveillance & & & & & - & - \\
\hline & & & & & Brain, MPNST & High (14-22\%) & Limited & Surveillance & - & - \\
\hline \multirow[t]{2}{*}{$R A D 51 C$} & 3 & Low $(15-40 \%)$ & Limited & Based on FH & & & & & PARPi & $\begin{array}{c}\text { Off label/ } \\
\text { Clinical trials }\end{array}$ \\
\hline & & & & & Ovarian & High $(>10 \%)$ & Strong & RRS, Surveillance & PARPi & $\begin{array}{c}\text { Off label/ } \\
\text { Clinical trials }\end{array}$ \\
\hline \multirow[t]{2}{*}{$B L M$} & 2 & Unknown & Insufficient & - & & & & & PARPi & Clinical trials \\
\hline & & & & & Colorectal & Unknown & Limited & - & PARPi & Clinical trials \\
\hline $\begin{array}{l}\text { ABRAXAS1 } \\
\text { (FAM175A }\end{array}$ & & Unknown & Insufficient & - & & - & - & & & \\
\hline
\end{tabular}

Table I. Continued 
Table I. Continued

\begin{tabular}{|c|c|c|c|c|c|c|c|c|c|c|}
\hline \multirow[b]{2}{*}{ Gene } & \multicolumn{4}{|c|}{ Breast cancer risk } & \multicolumn{4}{|c|}{ Other cancer risk } & \multicolumn{2}{|c|}{ Treatment actionability } \\
\hline & Cases & Risk & Evidence & Management & Type & Risk & Evidence & Management & Category & y Evidence \\
\hline \multirow[t]{3}{*}{ FANCA } & 4 & Unknown & Insufficient & - & & & & & PARPi & Off label/ \\
\hline & & & & & Ovarian & Unknown & Insufficient & - & PARPi & $\begin{array}{l}\text { Clinical trials } \\
\text { Clinical trials }\end{array}$ \\
\hline & & & & & Prostate & Unknown & Insufficient & - & PARPi & $\begin{array}{c}\text { Off label/ } \\
\text { Clinical trials }\end{array}$ \\
\hline \multirow[t]{5}{*}{ FANCM } & 4 & Unknown & Insufficient & - & & & & & PARPi & Off label/ \\
\hline & & & & & & & & & & Clinical trials \\
\hline & & & & & Ovarian & Unknown & Insufficient & - & PARPi & Clinical trials \\
\hline & & & & & Prostate & Unknown & Insufficient & - & PARPi & Off label/ \\
\hline & & & & & & & & & & Clinical trials \\
\hline \multirow[t]{2}{*}{ MRE11 } & 1 & Unknown & Insufficient & Based on FH & & & & & PARPi & Clinical trials \\
\hline & & & & & Prostate & Unknown & Insufficient & - & PARPi & $\begin{array}{c}\text { Off label/ } \\
\text { Clinical trials }\end{array}$ \\
\hline MUTYH & 30 & Unknown & Insufficient & Based on FH & & & & & - & - \\
\hline \multirow[t]{3}{*}{ monoalleli } & & & & & Colorectal & Increased & Limited & Surveillance & - & - \\
\hline & & & & & Endometrialf & otentially Increased & d Limited & - & - & - \\
\hline & & & & & Gastric & Increased & Limited & - & - & - \\
\hline \multirow[t]{7}{*}{ PMS2 } & 9 & $\begin{array}{l}\text { Unknown/ } \\
\text { Low }(<12 \%)\end{array}$ & Insufficient & Based on FH & & & & & ICI & 1B \\
\hline & & & & & Ovarian & Low $(1-2 \%)$ & Limited & RRS, Surveillance & ICI & 1B \\
\hline & & & & & Colorectal & High $(9-20 \%)$ & Strong & Surveillance & ICI & $1 \mathrm{~B}$ \\
\hline & & & & & Endometrial & High (13-26\%) & Strong & RRS, Surveillance & ICI & 1B \\
\hline & & & & & Gastric & Unknown & Insufficient & - & ICI & $1 \mathrm{~B}$ \\
\hline & & & & & Pancreatic & Unknown & Insufficient & - & ICI & $1 \mathrm{~B}$ \\
\hline & & & & & Prostate & Unknown & Insufficient & - & ICI & $1 \mathrm{~B}$ \\
\hline$R A D 50$ & 18 & Unknown & Insufficient & Based on FH & & & & & PARP & Clinical trials \\
\hline$R A D 51 B$ & 1 & Unknown & Insufficient & - & & & & & - & - \\
\hline$X R C C 2$ & 1 & Unknown & Insufficient & - & & & & & - & - \\
\hline
\end{tabular}

RRS: Risk-reducing surgery; FH: family history; PARPi: poly (ADP-ribose) polymerase inhibitors; ICI: immune checkpoint inhibitors. *Risk estimates are based on only on frameshift pathogenic/likely pathogenic variants. For the c.470T>C(p.Ile157Thr) variant the risk for breast cancer appears to be lower. **Breast cancer risks refer only to the c.657del5 variant.

\section{Discussion}

Testing selection criteria. In our cohort, for $81.0 \%$ $(1715 / 2117)$ of tested individuals, genetic testing was clinically indicated as described in NCCN (15) guidelines based on personal and family history information. Although the updated guidelines describe the clinical indication of genetic testing to a much broader group of individuals, still approximately $10 \%(41 / 415)$ of individuals positive for pathogenic variants would have been missed if strict selection criteria were applied (15). Despite the recent updates, selection criteria based on personal and family history information perform better in identifying $B R C A 1 / 2$ and other high breast cancer risk positive individuals compared to individuals with pathogenic variants in other breast cancer associated moderate and low-risk genes (Table III). These families, due to the fact that they carry pathogenic variants in genes with lower penetrance, fail to exhibit the characteristics of high-risk families and therefore be selected for genetic testing due to family history information (19).

High-risk genes for breast cancer. Approximately half of individuals tested positive had pathogenic variants in genes with very ong or strong evidence for increased risk of breast cancer and specifically $>60 \%$ absolute lifetime risk. Similar rates within positive reports have been described in recent studies ranging from $58 \%$ in population-based studies (20) of breast cancer patients to $84 \%$ in highly selected breast cancer patients (2). Consequently, these genes (BRCAl, BRCA2, PALB2, PTEN and TP53) have specific clinical management guidelines which often include the discussion of risk reducing surgeries (RRM) for breast cancer. Some of these genes are associated with cancer syndromes (PTEN Cowden Syndrome, TP53 - Li Fraumeni Syndrome) which have specific management recommendations. Moreover, these patients are informed about the additional evidence for 
Table II. Demographic and clinical characteristics for individuals referred for genetic testing.

\begin{tabular}{lcc}
\hline Demographic/Clinical & $\begin{array}{c}\text { All tested } \\
\text { individuals }\end{array}$ & $\begin{array}{c}\text { All tested positive } \\
\text { for P/LP variants }\end{array}$ \\
\hline Male & 16 & 3 \\
Female & 2101 & 412 \\
Age at diagnosis (years) & $44.9 \pm 10.4$ & $42.9 \pm 10.0$ \\
Mean \pm SD & $43(21-94)$ & $42(22-81)$ \\
Median (range) & & \\
Age at testing (years) & $47.3 \pm 11.1$ & $45.4 \pm 11.0$ \\
Mean \pm SD & $46(23-94)$ & $43(23-84)$ \\
Median (range) & $\mathrm{n}(\%)$ & $\mathrm{n}(\%)$ \\
Clinical status & $1884(89.0 \%)$ & $391(94.2 \%)$ \\
Affected & $233(11.0 \%)$ & $24(5.8 \%)$ \\
Unaffected & $\mathrm{n}(\%)$ & $\mathrm{n}(\%)$ \\
Family history of cancer & $837(39.5 \%)$ & $214(51.6 \%)$ \\
Breast cancer & $132(6.2 \%)$ & $52(12.5 \%)$ \\
Ovarian cancer & $252(11.9 \%)$ & $71(17.1 \%)$ \\
Colorectal cancer & $88(4.2 \%)$ & $23(5.5 \%)$ \\
Pancreatic cancer & $164(7.7 \%)$ & $53(12.8 \%)$ \\
Prostate cancer & $18(0.9 \%)$ & $6(1.4 \%)$ \\
Endometrial cancer & $102(4.8 \%)$ & $21(5.1 \%)$ \\
No cancer & $727(34.3 \%)$ & $54(13.0 \%)$ \\
Unknown & & \\
\hline
\end{tabular}

P/LP: Pathogenic/likely pathogenic.

high-, moderate- or low- risk association with other cancer types (e.g., ovarian, pancreatic, prostate, colorectal, endometrial) based on their test results. Therefore, genetic testing in these cases provides actionable information that is used for the guidance of risk reduction management decisions. Additionally, such results assist towards the identification of at-risk family members who would benefit from cascade family testing since the higher risk association and the specific management guidelines can act as convincing factor and an additional motive for other members of the family to undergo genetic testing.

An interesting example of a family in this category is depicted in Figure 3. A 43-year-old female (III:2) was diagnosed with breast cancer with no family history of breast cancer. Genetic testing was clinically indicated as she developed breast cancer at age $<45$ years. Multi-gene panel testing revealed the BRCAl pathogenic variant NM_007294.4(BRCA1):c.181T>G (p.Cys61Gly) and the low penetrance pathogenic variant NM_007194.4(CHEK2):c.470T>C (p.Ile157Thr) in CHEK2. The proband receives important information about her breast cancer management with the discussion of risk-reducing options and/or increased screening as she has an increased contralateral breast cancer risk (21) (45\% lifetime risk up to the age of 85 ).

In addition, her $B R C A l$ positive result provides treatment recommendations as international guidelines suggest treatment with PARPis for patients with germline or somatic
BRCA1/2 mutations. Moreover, she receives information for her increased risk of other cancer types as ovarian and pancreatic cancer. In specific, she has a high risk of ovarian cancer with available risk-reductions management recommendations and a moderate risk for pancreatic cancer that could advice an increased surveillance although there is no family history of these cancer types. The low penetrance variant in CHEK2 may contribute to her increased risk for breast cancer and increases the risk for colorectal cancer suggesting earlier screening for colorectal cancer than the age of 50. First degree relatives of the patient have up to $50 \%$ risk of having the same variants and genetic counseling was provided to the family. The mother of the patient (II:3) was tested for the same variants but carried only the pathogenic variant in BRCA1. This information enables more aggressive screening of this family member for breast, ovarian and pancreatic cancer. Moreover, the combination of the absence of the CHEK2 variant and her health status may suggest a synergistic effect of the multiple pathogenic variants in her daughter. Experimental studies have shown that this missense variant in $C H E K 2$ reduces the binding of the CHEK2 protein to $\mathrm{Cdc} 25 \mathrm{~A}, \mathrm{BRCA} 1$ and $\mathrm{p} 53$ proteins in vitro and may have a dominant-negative effect in cells, although it does not have an effect on CHEK2 protein kinase activity (22-26). Genetic testing in this family affects multiple family members and the results provide evidence for an increased risk of additional cancer types in the family and assist towards cancer prevention actions.

Moderate-risk genes for breast cancer. A substantial percentage of individuals tested positive in breast cancer (approximately 16\%) have $\mathrm{P} / \mathrm{LP}$ variants in moderate penetrance genes (ATM, CHEK2, NBN). This proportion of breast cancer patients within positive reports has been reported up to $25 \%$ in recent population-based studies (20) or approximately $9 \%$ in highly selected breast cancer patients (2). In particular, for the ATM and CHEK2 genes there is strong evidence for the risk association but with a lower absolute lifetime risk ranging from $15-40 \%$. Screening and risk-reduction management in international guidelines is mainly extrapolated in these cases by $B R C A 1 / 2$ data based on the levels of risk. Management takes into account family history information and further clinical data that are available to physicians in each case. However, there is an adequate amount of data from case-controls studies to calculate personalized risk levels for carriers of ATM and CHEK2 pathogenic variants.

In addition, there are specific alleles, especially the c. $470 \mathrm{~T}>\mathrm{C}$ variant in $C H E K 2$ that are associated with a lower risk for breast cancer and should be considered when reporting such variants and using them to guide management. Although not present in our cohort, there are also certain $A T M$ pathogenic variants that are associated with 
415 BC patients or healthy individuals with FH of BC tested positive for P/LP variants

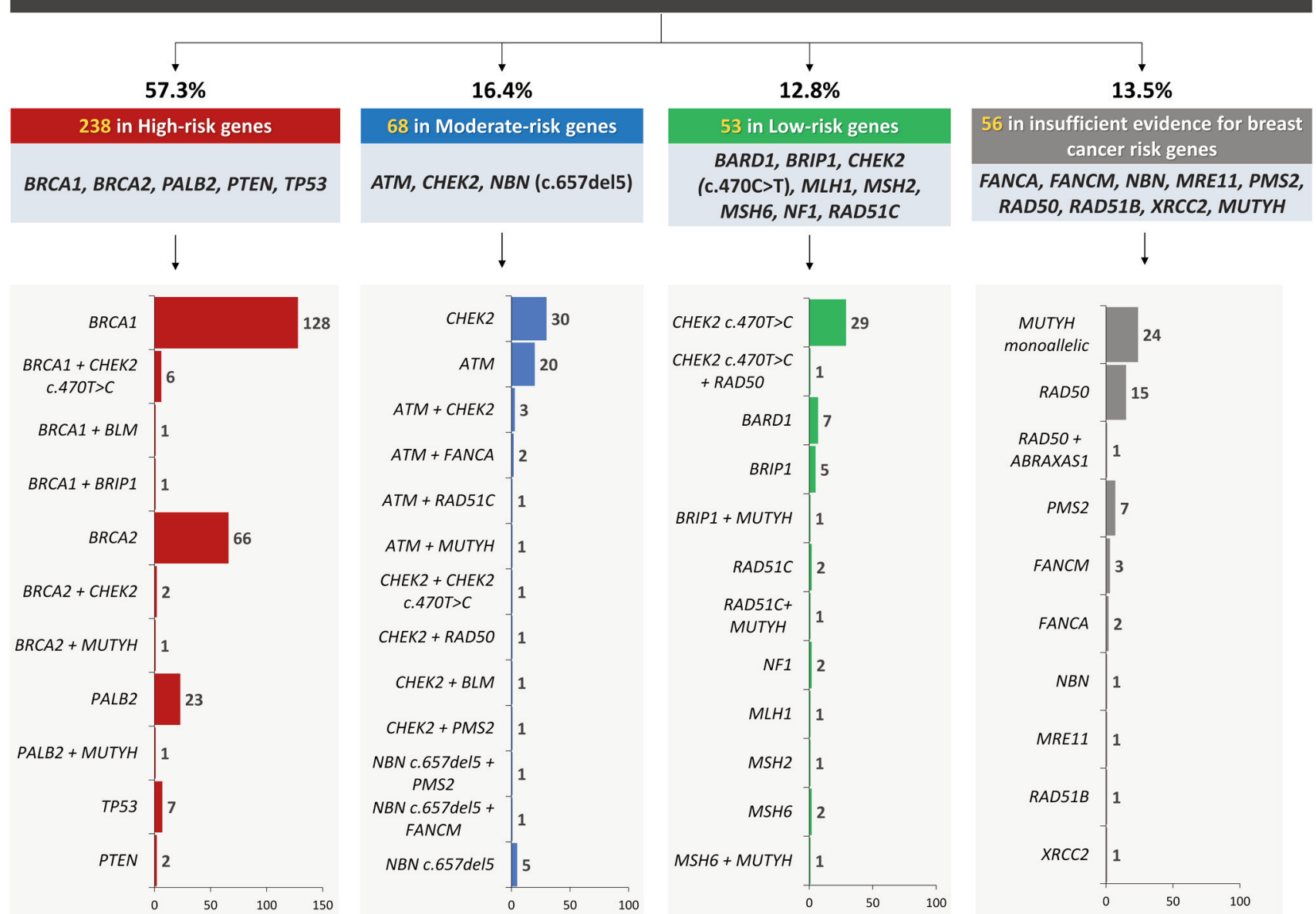

Figure 1. Summary of individuals with pathogenic/likely pathogenic $(P / L P)$ variants categorized by breast cancer $(B C)$ risk. In each group, the gene incidence of pathogenic/likely pathogenic variants and double heterozygotes are shown. CHEK2:c.470T>C and NBN:c.657del5 results are separated with variant specific breast cancer risk levels.

an increased (high) risk for early onset breast cancer and bilateral breast cancer $(27,28)$.

The majority of the cases with pathogenic variants identified in NBN (7 out of 8) carried the 657del5 frameshift causing variant (p.Lys219Asnfs*16) that has been described as a pathogenic founder variant of Slavic and Eastern European origin and is the most common pathogenic variant in patients with the related autosomal recessive condition called Nijmegen Breakage syndrome. There is evidence for increased breast cancer risk for carriers of the c.657del5 variant in $N B N$ compared to a lower or non-significant risk for carriers of other pathogenic/likely pathogenic variants in this gene (8). Therefore, these variant reports should include variant specific information about the associated risk along with information about the mutated gene as in this category there are certain examples of variants or variant types that have adequate data to calculate variant-level associated breast cancer risks. Variant specific cancer risks should be taken into consideration when interpretating test results for moderate penetrance genes.

In Figure 4, we describe the example of a family with no family history of breast cancer and genetic testing not clinically indicated according to international guidelines. The female proband was diagnosed with breast cancer at the age of 49 and was tested at the age of 60. Multi-gene panel testing identified the NM_000051.3(ATM):c.8988-1G>C pathogenic variant. This variant is expected to result in incorrect splicing and removal of the entire exon in the resulting ATM protein and has been described in the international literature in association with ataxiatelangiectasia (29). This test result may explain her personal history of breast cancer and better estimates her risk for 


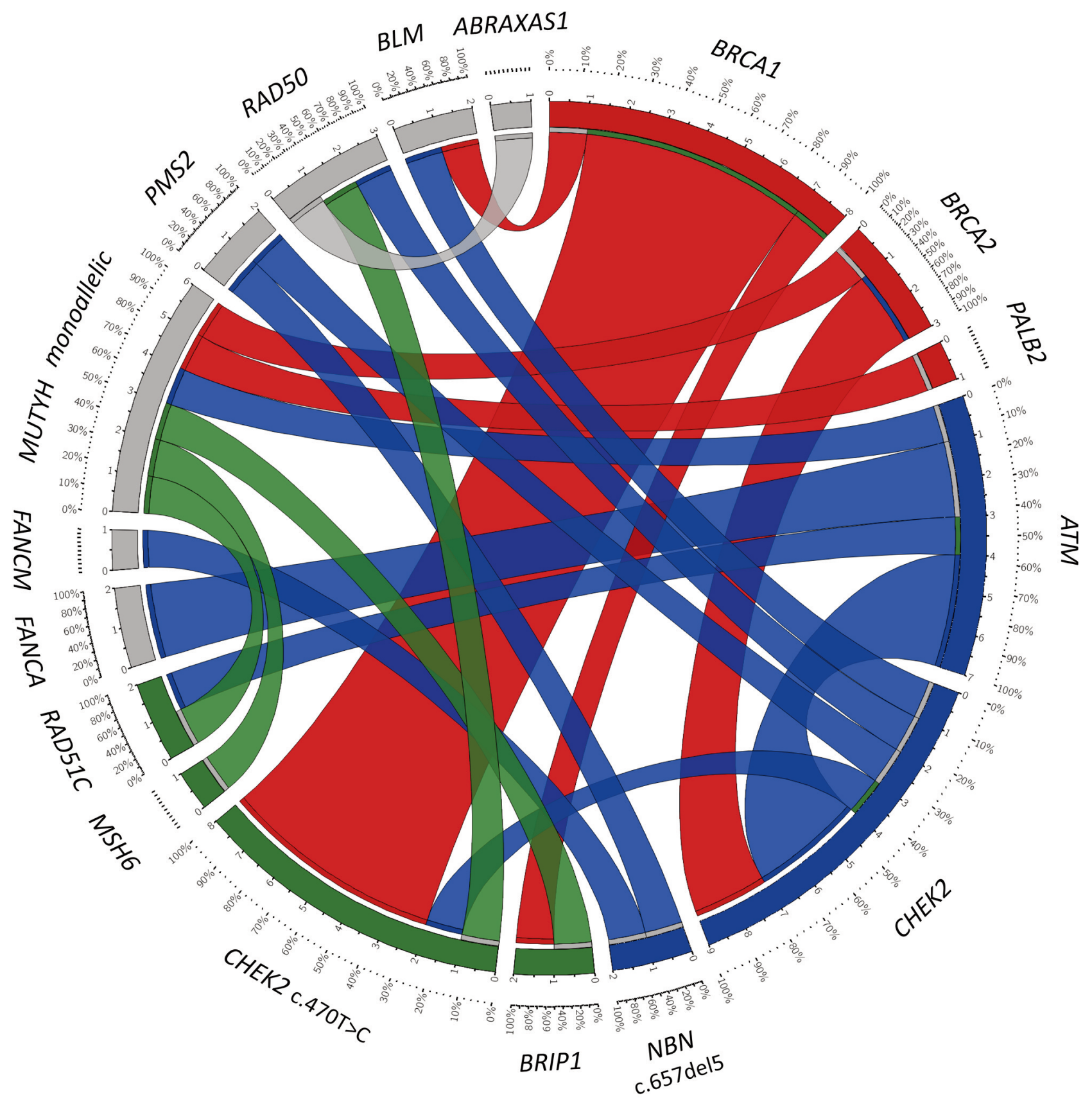

Figure 2. Combinations of genes in cases with two pathogenic variants (double heterozygotes). High-, moderate-, low- and insufficient evidence for breast cancer risk genes are highlighted with red, blue, green, and grey ribbons/tracks, respectively. Visualization was performed using Circos (41).

breast cancer providing evidence to guide her management options. Moreover, she is informed about her slightly increased risk of ovarian cancer and a moderate risk $(\sim 4 \%$ to the age of 85) of pancreatic cancer. The association of ATM with colorectal cancer is not well established so her associated colorectal cancer risk is uncertain. After genetic counselling provided to the family, 4 members proceeded with cascade family testing. Her two brothers (III:3 and III:4) and her two daughters (IV:1 and IV:2) were tested for the identified pathogenic ATM variant and individuals III:4 and IV:2 were found positive. Individuals IV:1 and III:3 are informed that they do not have an elevated cancer risk at 
A

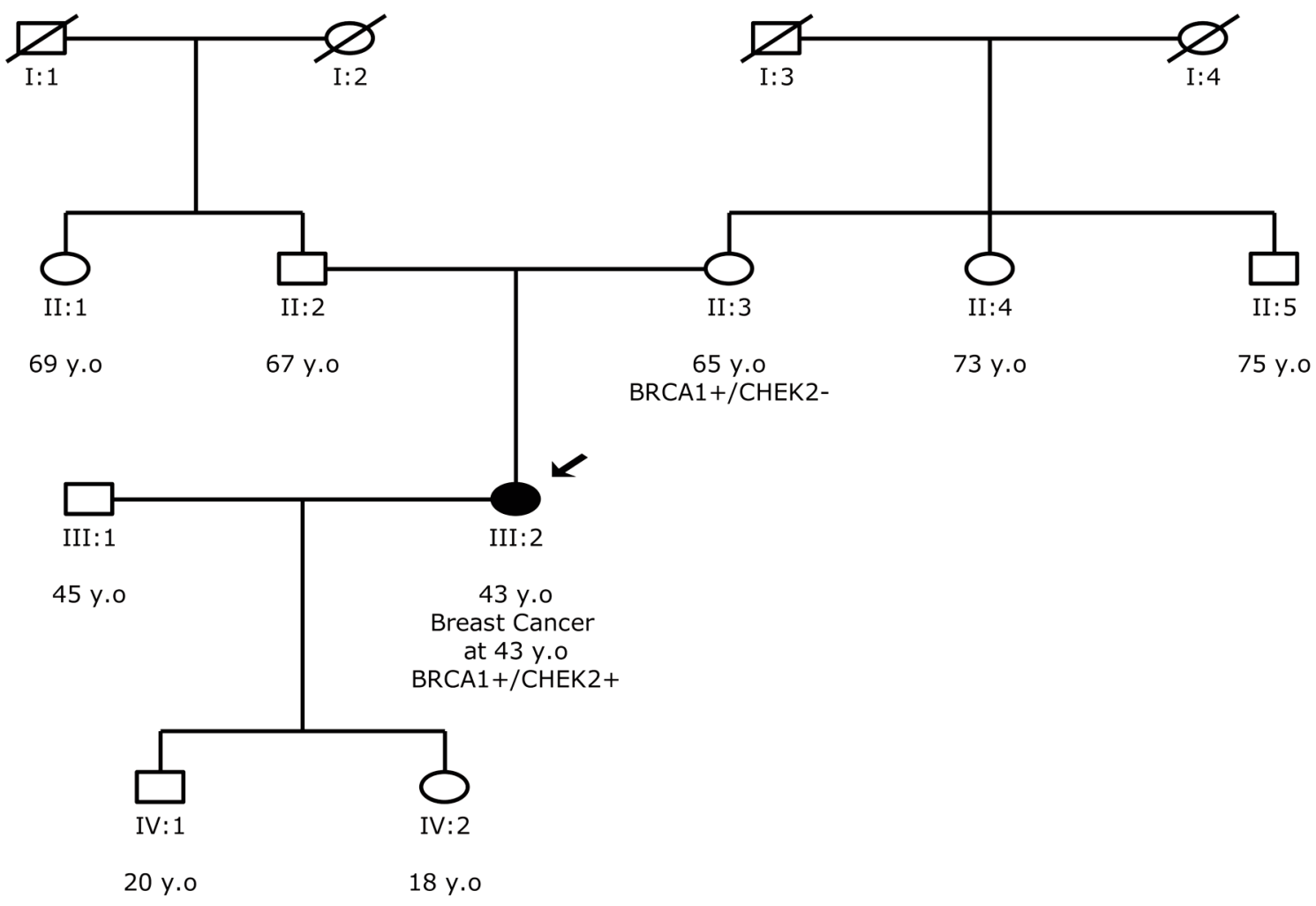

B

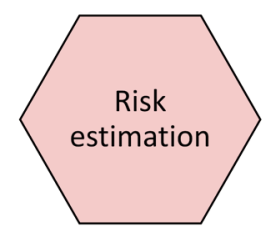

BRCA1

CHEK2

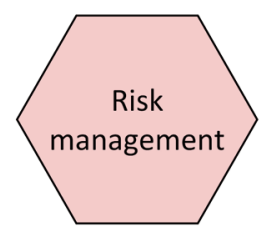

BRCA1

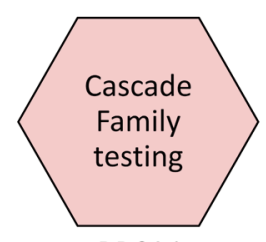

BRCA1

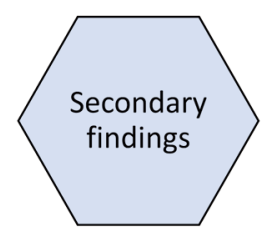

CHEK2

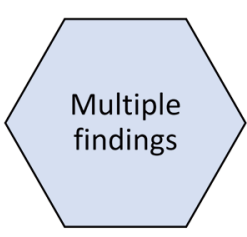

BRCA1/CHEK2

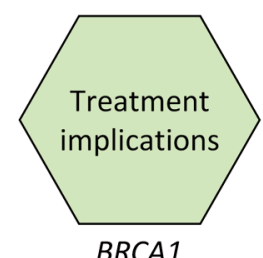

BRCA1 BRCA1/CHEK2 ?

Figure 3. Example of a patient (double heterozygote) with a pathogenic variant in a high-risk gene (BRCA1) and a low penetrance pathogenic variant in a moderate-risk gene (CHEK2). (A) The pedigree of the family. (B) The clinical actionability of germline testing in this family through the different levels of information received after the disclosure of the results (red: breast cancer risk estimation and management, blue: risk estimation and management associated with other cancer types, green: evidence-based information for treatment selection). Due to the identification of two pathogenic variants, this information differentiates between the two findings and/or their co-occurrence.

Table III. The performance of NCCN selection criteria (Version 2.2021) (15) for genetic testing in breast cancer to identify individuals with pathogenic/likely pathogenic variants in each gene risk group.

\begin{tabular}{|c|c|c|c|c|c|c|c|}
\hline $\begin{array}{l}\text { Meeting NCCN } \\
\text { selection criteria? }\end{array}$ & $\begin{array}{l}\text { Negative } \\
\text { or VUS }\end{array}$ & $\begin{array}{l}\text { All tested } \\
\text { positive }\end{array}$ & BRCA1/2 & High-risk & Moderate-risk & Low-risk & $\begin{array}{c}\text { Insufficient } \\
\text { evidence }\end{array}$ \\
\hline Yes & $1,341(78.8 \%)$ & $374(90.1 \%)$ & $196(95.6 \%)$ & $227(95.4 \%)$ & $65(86.7 \%)$ & $38(84.4 \%)$ & $44(77.2 \%)$ \\
\hline No & $361(21.2 \%)$ & $41(9.9 \%)$ & $9(4.4 \%)$ & $11(4.6 \%)$ & $10(13.3 \%)$ & $7(15.6 \%)$ & $13(22.8 \%)$ \\
\hline$p$-Value* & $<0.0001$ & 0.0217 & - & 0.9195 & 0.0086 & 0.0056 & $<0.0001$ \\
\hline
\end{tabular}

VUS: Variants of uncertain significance. *Evaluation of the statistical significance of the difference on the selection performance (\% yes) of each group compared to the BRCAl/2 group. 
A

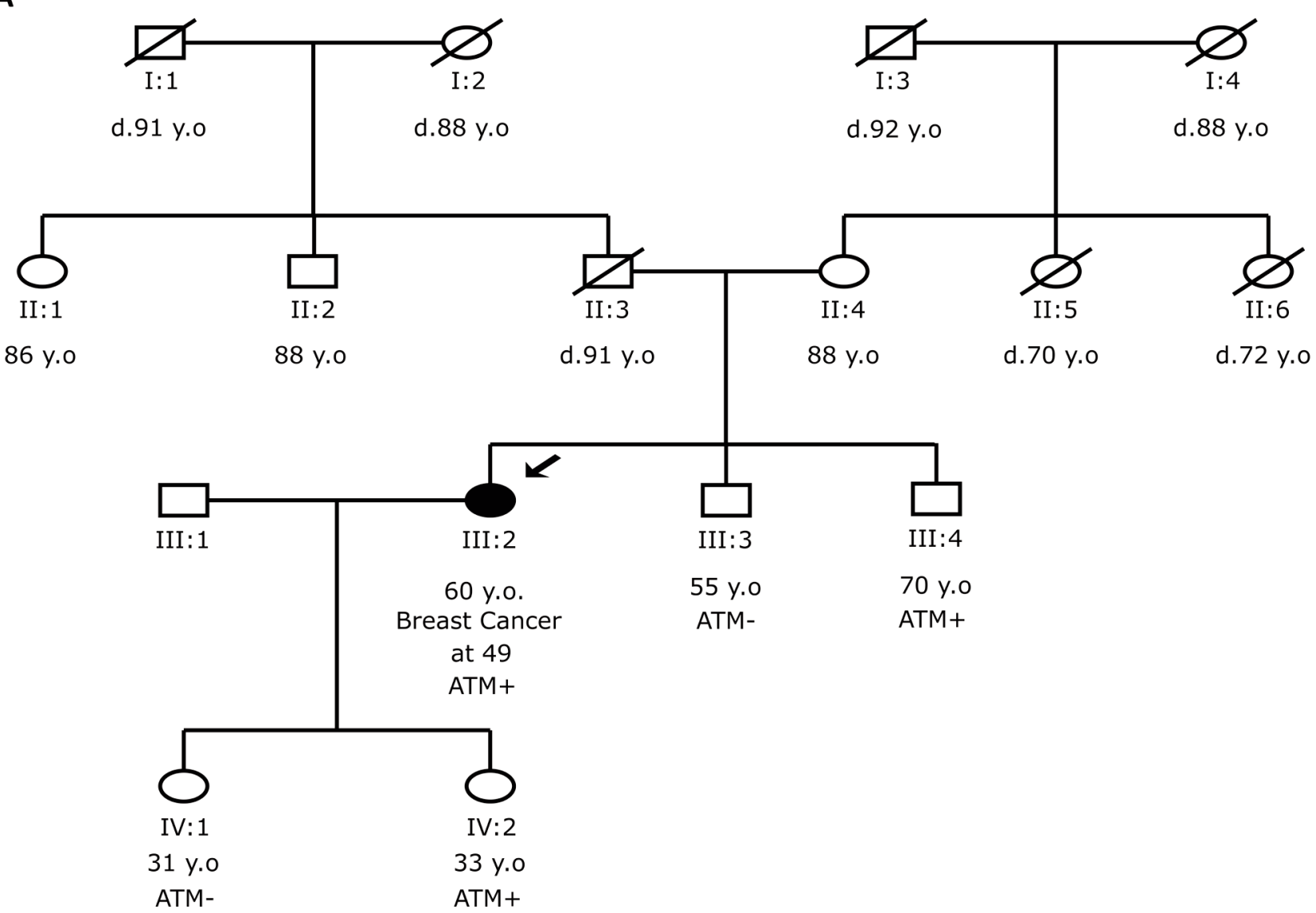

B
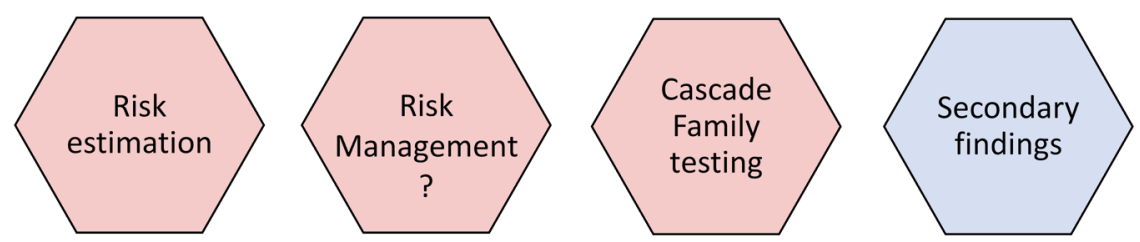

Figure 4. Example of a patient with a pathogenic variant in a moderate-risk gene (ATM). (A) The pedigree of the family. (B) The clinical actionability of germline testing in this family through the different levels of information received after the disclosure of the results (red: breast cancer risk estimation and management, blue: risk estimation associated with other cancer types).

least for the portion of the ATM-associated cancer risk in their family. On the other hand, her brother (III:4) is getting information about his increased ATM-associated risk of pancreatic and prostate cancer and her daughter (IV:2) about her moderately increased risk of breast and pancreatic cancer. Such information could guide screening of these individuals towards cancer prevention.

Low-risk genes for breast cancer.Pathogenic variants identified in BARD1, BRIP1, MLH1, MSH2, MSH6, NF1 and $R A D 51 C$ are associated with a potential lower absolute lifetime risk for breast cancer $(<15 \%)$ but with insufficient evidence in most cases for an accurate estimation. In our cohort $12.8 \%$ of positive results fell in this category. Similar rates within positive reports have been described recently ranging from $11 \%$ in population-based studies (20) of breast cancer patients to $7 \%$ in highly selected breast cancer patients (2). In these cases, management associated with breast cancer risk is mainly based of personal and family history characteristics. However, genes in this category are often associated with other cancer types with enough evidence to make specific management recommendations, 
A

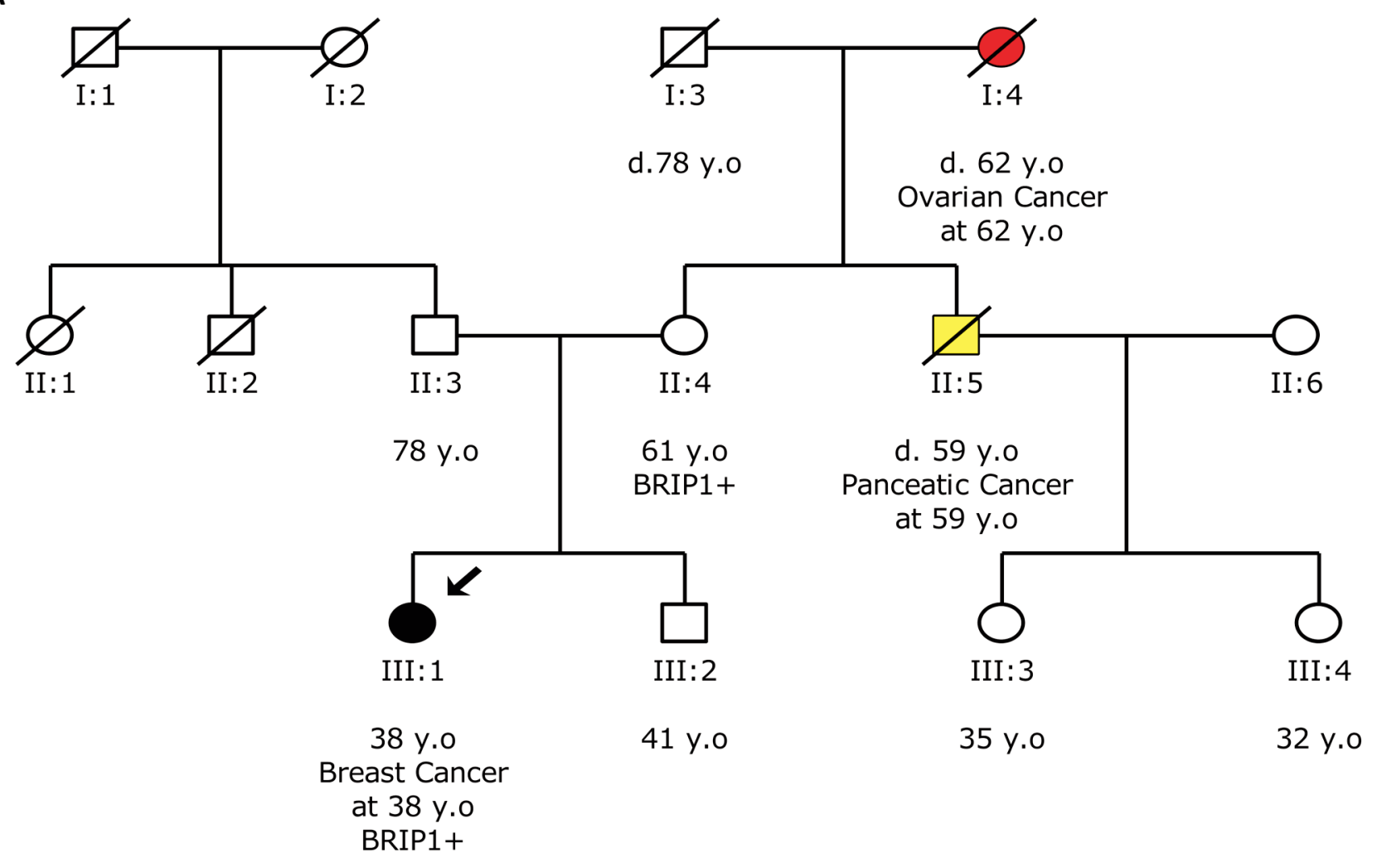

B
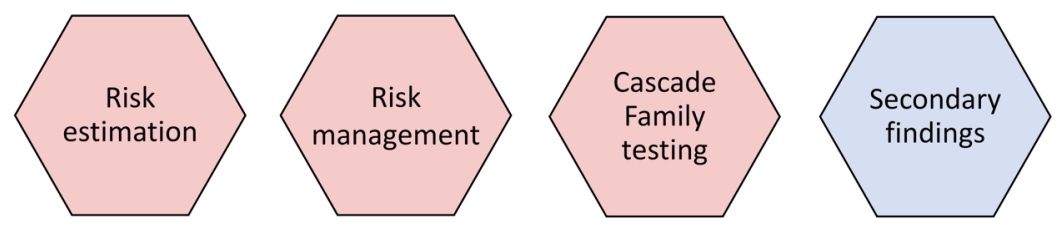

Figure 5. Example of a patient with a pathogenic variant in a low-risk gene (BRIP1). (A) The pedigree of the family. (B) The clinical actionability of germline testing in this family through the different levels of information received after the disclosure of the results (red: breast cancer risk estimation and management, blue: risk estimation associated with other cancer types).

such as ovarian and colorectal cancer. In our cohort, $17 \%$ $(9 / 53)$ of cases in this category had a P/LP variant in highrisk genes for ovarian cancer $(B R I P 1, R A D 51 C)$ and $9.4 \%$ $(5 / 53)$ had a P/LP variant in high-risk colorectal cancer genes (MLH1, MSH2, MSH6). These individuals, although they do not receive specific actionable information for breast cancer, they are presented with information about other cancer types and their personalized risk, so as to make informed decisions and begin screening surveillance. This potential scenario, of test results in this category, should be discussed in detail during their pre-test genetic counselling.

An example of a family in this category is descripted in Figure 5. A 38-year-old female (III:1) diagnosed with breast cancer was referred for testing and reported family history of ovarian and pancreatic cancer from her mother's family side. The pathogenic variant NM_032043.3(BRIP1):c.2392C >T (p.Arg798Ter) was identified. BRIP1 is described as a low-risk breast cancer gene and guidelines suggest breast cancer management based on family history as there are insufficient data for an accurate risk estimation. This variant has been described as a recurrent disease-causing mutation in both Fanconi anemia type-J (FA-J) and breast cancer patients (3034). However, this patient is also introduced with an additional increased risk of ovarian cancer as there is strong evidence for high risk $(>10 \%)$ of ovarian cancer in carriers of BRIPI pathogenic/likely pathogenic variants. Multi-gene panels 
Table IV. Treatment implications of germline findings in hereditary cancer predisposition genes with pathogenic/likely pathogenic variants in our cohort.

\begin{tabular}{|c|c|c|c|}
\hline Gene/Biomarker & Cancer type & Drug & Evidence level \\
\hline$B R C A 1 / 2$ & Breast & Olaparib, Talazoparib & Approved $(42,43)$ \\
\hline$B R C A 1 / 2$ & Pancreatic & Olaparib & Approved (44) \\
\hline$B R C A 1 / 2$ & Ovarian & $\begin{array}{l}\text { Olaparib, Rucaparib, } \\
\text { Niraparib, Talazoparib }\end{array}$ & Approved (45-48) \\
\hline $\begin{array}{l}\text { BRCA1/2, ATM, BRIP1, BARD1, } \\
\text { CHEK2, PALB2, RAD51C, RADB1D }\end{array}$ & Prostate & Olaparib & Approved (36) \\
\hline$B R C A 1 / 2$ & Breast & Carboplatin & Well-powered studies (49) \\
\hline$B R C A 1 / 2$ & Ovarian & Carboplatin & Well-powered studies (50) \\
\hline MLH1, MSH2, MSH6, PMS2, EPCAM & All tumors & $\begin{array}{l}\text { Pembrolizumab, Nivolumab, } \\
\text { Atezolizumab, Durvalumab }\end{array}$ & Well-powered studies $(10,11)$ \\
\hline POLE, POLD1 & All tumors & $\begin{array}{l}\text { Pembrolizumab, Nivolumab, } \\
\text { Atezolizumab, Durvalumab }\end{array}$ & Well-powered studies $(10,11)$ \\
\hline ATM & Gastric & Olaparib & Preclinical studies (51) \\
\hline$A T M$ & Pancreatic & Olaparib & Preclinical studies (52) \\
\hline $\begin{array}{l}\text { BRCA1/2, ATM, BARD1, BRIP1,CHEK2, } \\
\text { MRE11, PALB2, RAD51C, RAD51D }\end{array}$ & Ovarian & $\begin{array}{l}\text { Platinum-based } \\
\text { agents }\end{array}$ & Preclinical studies (53) \\
\hline $\begin{array}{l}\text { BARD1, BRIP1, FANCA, NBN, PALB2, } \\
\text { RAD51C, RAD51D }\end{array}$ & All tumors & Rucaparib & Clinical trials; [NCT04171700] \\
\hline $\begin{array}{l}\text { ATM, BRIP1, BARD1, BLM, CHEK2, MRE11, } \\
\text { NBN, PALB2, POLD1, PTEN, RAD50 }\end{array}$ & All tumors & Niraparib & Clinical trials; [NCT03207347] \\
\hline $\begin{array}{l}A T M, B A R D 1, B R I P 1, C H E K 2, F A N C A, F A N C M, \\
M R E 11, N B N, P A L B 2, R A D 50, R A D 51 C, R A D 51 D\end{array}$ & Breast & Olaparib & Clinical trials; [NCT03344965] \\
\hline $\begin{array}{l}\text { PTEN, PALB2, CHEK2, ATM, NBN, BARD1, BRIP1, } \\
\text { RAD50, RAD51C, RAD51D, MRE11, FANCA }\end{array}$ & Breast & Talazoparib & Clinical trials; [NCT02401347] \\
\hline $\begin{array}{l}\text { BRCA1/2, PALB2, CHEK2, ATM, BARD1, BLM, } \\
\text { BRIP1, FANCA, FANCM, MRE11, NBN, PTEN, } \\
\text { RAD50, RAD51C, RAD51D }\end{array}$ & Breast & $\begin{array}{l}\text { HX008 (anti-PD-1) + } \\
\text { Niraparib }\end{array}$ & Clinical trials; [NCT04508803] \\
\hline
\end{tabular}

identify pathogenic variants in genes not primarily associated with the referred phenotype. However, such genes provide information for predisposition to other cancer types. In this regard, the $B R I P 1$ variant in this individual is regarded as a secondary finding. We argue that this term should not imply an unexpected finding but rather additional information that is the benefit of using multi-gene panels. In this case, the BRIPI pathogenic finding is clinically significant, and actionable information as international guidelines suggest the consideration of risk-reducing salpingo-oophorectomy at the age of 45-50y for the prevention of ovarian cancer. Moreover, since BRIP1 is a gene involved in the homologous recombination pathway she receives information about potential response to treatment with PARPi (35) as their use is approved for BRIPl and other highrisk (HR) genes with somatic variants in prostate cancer (36) and is under investigation for HR genes in several ongoing clinical trials (Table IV). First degree relatives of the patient have up to $50 \%$ risk of having the same variants and genetic counseling was provided to the family. The mother of the patient (II:5) was tested and found positive for this pathogenic variant in BRIP1. As being a healthy individual, she receives valuable information for increased surveillance for breast and ovarian cancer based on her family history of cancer and may consider the option of risk-reducing interventions for the prevention of ovarian cancer. Genetic testing in this family affects multiple family members and illustrates the effectiveness of testing other members at risk.

Genes with insufficient evidence for breast cancer risk. A small percentage of P/LP variants (56/415) are identified in genes (FANCA, FANCM, NBN, MRE11, PMS2, RAD50, $R A D 51 B, X R C C 2, M U T Y H)$ with unknown risk for breast cancer and insufficient evidence of further association. These genes are often included in routine genetic testing although they cannot give clear information about the associated breast cancer risk, but these data often act as a pool for further risk association studies and metanalysis. Here, is raised a problem with communication and genetic counselling of such results as they add an inherited uncertainty to positive results without giving answers to the initial reason of referral.

Double heterozygotes. A considerable number of tested individuals $(\sim 9 \%)$ carried two P/LP variants. Half of the 


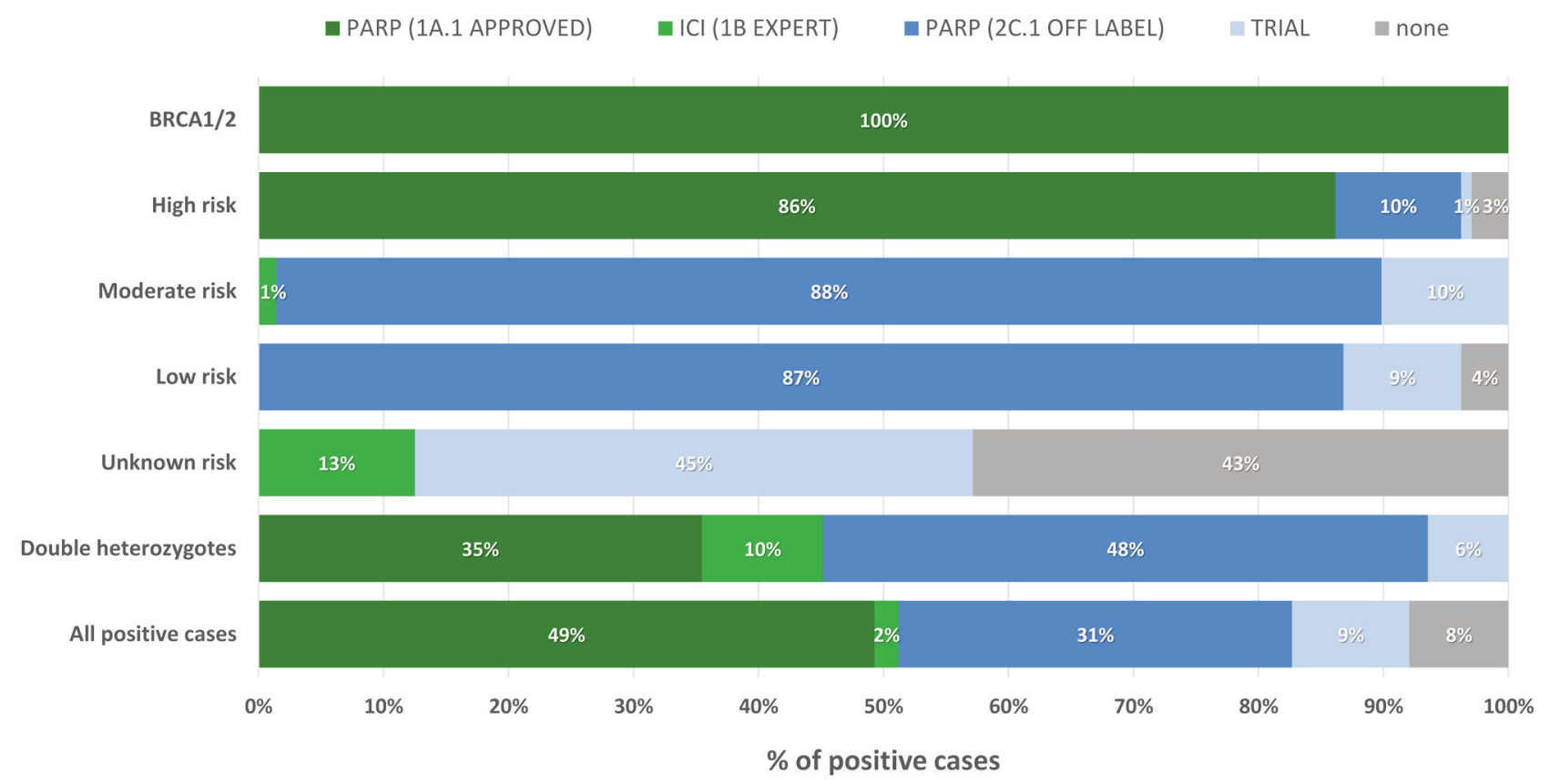

Figure 6. Treatment implications of germline findings in the 415 individuals with pathogenic/likely pathogenic variants grouped by the level of breast cancer risk.

cases, involved MUTYH heterozygotes and carriers of the low penetrance c.470T $>C$ (p.Ile157Thr) pathogenic variant in CHEK2. In both cases there is limited evidence to support an increased risk for breast cancer. However, in other double heterozygotes, P/LP variants were identified in genes with risk associations for multiple cancer types or even association with breast cancer risk at different risk levels (e.g., family in Figure 3). Similar results have been reported in the literature and have been described as Multilocus Inherited Neoplasia Alleles Syndrome (12). However, there is not enough data to determine if there is an additive or synergistic effect of gene defects in these cases (37). Further studies need to evaluate if they impose an increased risk compared to carriers of P/LP variants in the same single genes and whether they can be used as predictive biomarkers to PARPi especially in the case of double heterozygotes of HR genes. Nevertheless, they provide a good reason why reflex testing for germline mutations should be avoided. In some cases, the different mutated genes give information about multiple cancer types and may explain the genetic history of different sides of the family history and the occurrence of diverse cancers in the family (38).

Therapeutic implications. An important new level of information in hereditary cancer testing results is the association with potential therapies especially in cases with metastatic disease. This is mainly feasible since an important number of genes included in genetic testing have been used as predictive biomarkers for response to targeted therapies and in specific to PARPis. These genes are included in the Homologous Recombination (HR) pathway which is involved in the repair of DNA double-strand breaks and include: $A T M$, BARD1, BRCA1/2, BRIP1, CHEK2, FANCA, FANCM, MRE11, NBN, PALB2, RAD50, RAD51C and RAD51D. Moreover, protein defects in Lynch syndrome (LS)-associated mismatch repair genes (MLH1, MSH2, MSH6, PMS2, EPCAM) are associated with MSI and/or mismatch repair deficiency (MMR-D) and can subsequently be used as predictive biomarkers for anti-PD-1/PD-L1 immunotherapy efficacy $(10,11)$. Interestingly, 92\% (382/415) of individuals with positive results are linked to additional therapy selection information with different levels of clinical and/or experimental evidence (Figure 6). In specific, 49\% (205/415) of results include biomarkers that predict response to FDAapproved therapies for breast cancer mainly due to pathogenic variants in BRCAl/2 genes. 6\% (14/415) of results include biomarkers that could predict response to immunotherapy with ICIs based on well-powered studies with consensus from experts in the field. The remaining of the positive results $(31 \%, 130 / 415)$ include genes that can be used as potential biomarkers for response to PARPis in breast cancer (off label evidence-based drug use) since they include genes involved in the HR pathway shown to predict response to approved therapies in a different cancer type (prostate cancer). 

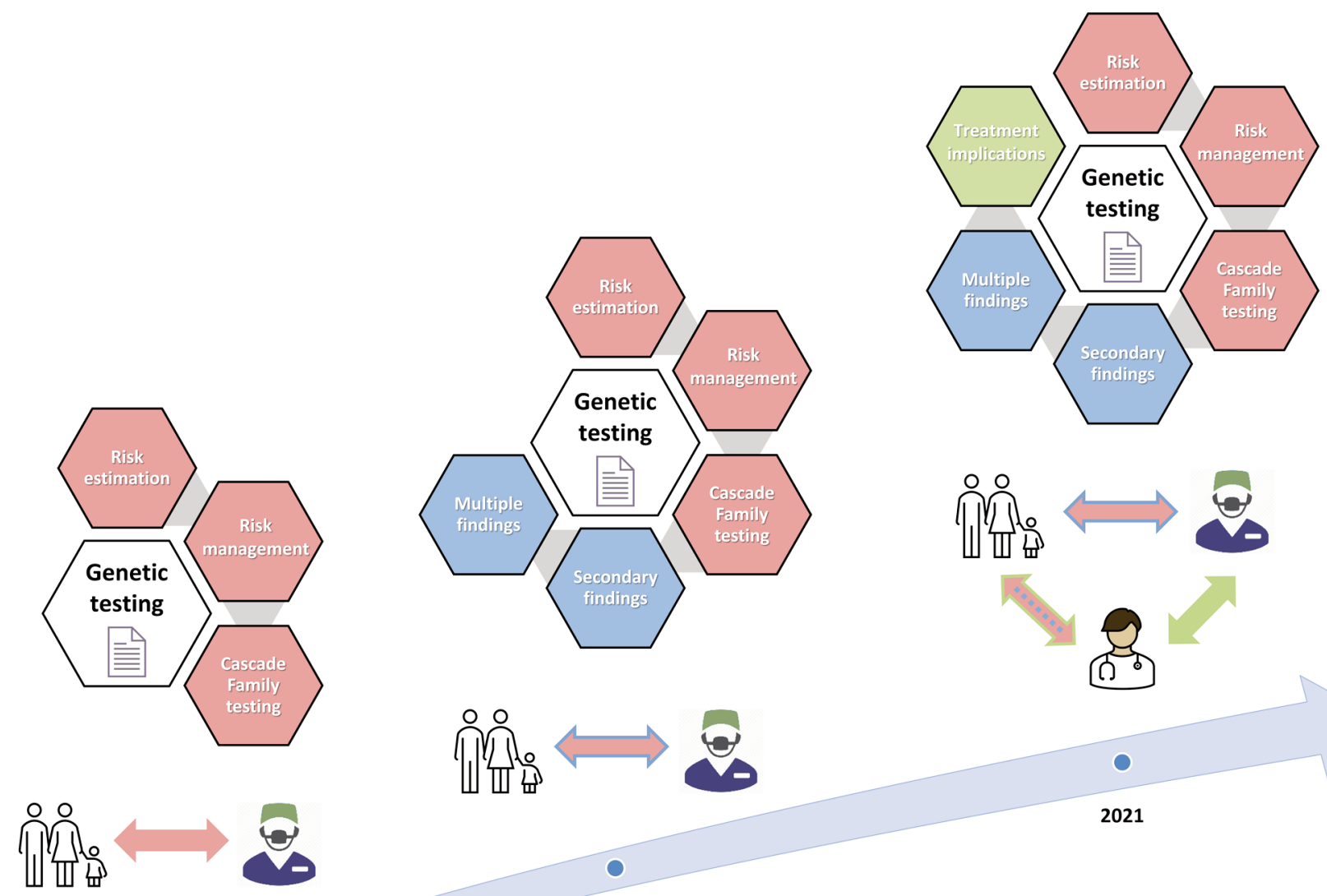

-

2021

Figure 7. The evolution of information retrieved from genetic testing in the last two decades. The different levels of information add quantitative and qualitative changes to the clinical utility of genetic testing. Different colors indicate these levels; red: risk estimation and management, blue: secondary findings and information for predisposition to other cancer types, green: evidence-based information for treatment selection. The interaction model nowadays includes the oncologist, the surgeon, and the family.

These data suggest that, in addition to risk assessment, breast cancer patients could benefit from genetic testing by receiving useful information to guide treatment selection. It is important to note that such information is available through the spectrum of different breast cancer risk association of genes and it is an added value when testing moderate-/low- risk genes for breast cancer. In the case of genes with limited information and association with an increased risk for breast cancer, we observe that the majority of them link to ongoing clinical trials that examine the response of these carriers to PARPis and may add actionable information in these results in the future.

Genetic counselling. Historically, genetic counselling is the communication process which deals with the human problems associated with the occurrence or risk of occurrence of a genetic disorder in a family. Nowadays, when communicating the results of the genetic test there are multiple levels of information that should be included and involve: 1) information about the way heredity contributes to breast cancer and how are the genes tested associated with different risk levels for breast cancer but also for other cancer types, 2) information about how results could affect the management of breast cancer in the patient, 3) actions associated with the reduction of the risk of occurrence/recurrence to the tested individual and specified relatives and 4) evidence based information on how testing results can be used for treatment selection using PARPis and/or immunotherapy (Figure 7).

All this information should be extracted from our current scientific knowledge in line with international guidelines and 
well powered studies and counselling should be provided in the pre- and post-testing setting. Cascade family testing should be encouraged, especially in the cases of positive findings for high-risk genes. Our data suggest that only approximately $10 \%$ of families tested positive continue with genetic testing of selected relatives and the process of family testing is underutilized. This has been shown to be irrelevant of the cost of testing $(39,40)$.

When a trained and certified genetic counselor is not involved in the process, all this information should be adequately communicated to the tested individual by the physician and/or the testing laboratory. The latter should include relevant information and proper language in the report of the results so that the report can act as a resource of our current actionable knowledge.

Evidence-based information included in the reports and the standardization of the reporting language can help towards this direction (13). Special efforts should be made to clearly describe findings in moderate-/low- risk genes and to describe the cases of double heterozygotes. In such cases the results, as discussed above, could be linked to increased risk for additional cancer types that would require additional management and/or referral to another expert.

\section{Conclusion}

The identification of P/LP variants in moderate- and low-risk genes imposes challenges in risk estimation but provides actionable information for other cancer risk associations. Moreover, P/LP variants are potential biomarkers for targeted therapies using PARPi and immunotherapies with ICIs. Therapeutic implications of germline findings are an additional level of information produced by genetic tests and could be included in a separate section in clinical reports. Reporting and pre-/post-genetic counseling should take into account these features. Improvement efforts should be focused on the actual use of genetic testing results for the management of patients. It is a matter of time to assess the influence of genetic testing results on clinical decisions and the impact of such information and management on patients' health outcomes.

\section{Conflicts of Interest}

There are no conflicts to declare.

\section{Authors' Contributions}

G.N.T drafted the manuscript and performed the bioinformatics and statistical analysis. G.N.T., E.P., N.T. and G.N. designed the study. E.P., K.A. and G.P. carried out the DNA extraction, sequencing and contributed to the analysis and interpretation of the variant data. I.B., T.F., R.I., O.K., A.K., C.M., K.P., V.V., A.K., A.P., G.X., E.B., D.T.E., A.B., D.L.S., A.U., V.O., S.T., M.T., and S.Y.; provided the materials, demographic data and family history. G.N. conceived of the study and participated in its design and coordination. All Authors read and approved the final manuscript.

\section{Acknowledgements}

The Authors would like to thank all the doctors who participated in this study and all the patients who consented to the use of their genetic material.

\section{References}

1 Yadav S and Couch FJ: Germline genetic testing for breast cancer risk: The past, present, and future. Am Soc Clin Oncol Educ Book 39: 61-74, 2019. PMID: 31099663. DOI: 10.1200/EDBK_238987

2 Breast Cancer Association Consortium, Dorling L, Carvalho S, Allen J, González-Neira A, Luccarini C, Wahlström C, Pooley KA, Parsons MT, Fortuno C, Wang Q, Bolla MK, Dennis J, Keeman R, Alonso MR, Álvarez N, Herraez B, Fernandez V, Núñez-Torres R, Osorio A, Valcich J, Li M, Törngren T, Harrington PA, Baynes C, Conroy DM, Decker B, Fachal L, Mavaddat N, Ahearn T, Aittomäki K, Antonenkova NN, Arnold N, Arveux P, Ausems MGEM, Auvinen P, Becher H, Beckmann MW, Behrens S, Bermisheva M, Białkowska K, Blomqvist C, Bogdanova NV, Bogdanova-Markov N, Bojesen SE, Bonanni B, Børresen-Dale AL, Brauch H, Bremer M, Briceno I, Brüning T, Burwinkel B, Cameron DA, Camp NJ, Campbell A, Carracedo A, Castelao JE, Cessna MH, Chanock SJ, Christiansen H, Collée JM, CordinaDuverger E, Cornelissen S, Czene K, Dörk T, Ekici AB, Engel C, Eriksson M, Fasching PA, Figueroa J, Flyger H, Försti A, Gabrielson M, Gago-Dominguez M, Georgoulias V, Gil F, Giles GG, Glendon G, Garcia EBG, Alnæs GIG, Guénel P, Hadjisavvas A, Haeberle L, Hahnen E, Hall P, Hamann U, Harkness EF, Hartikainen JM, Hartman M, He W, Heemskerk-Gerritsen BAM, Hillemanns P, Hogervorst FBL, Hollestelle A, Ho WK, Hooning MJ, Howell A, Humphreys K, Idris F, Jakubowska A, Jung A, Kapoor PM, Kerin MJ, Khusnutdinova E, Kim SW, Ko YD, Kosma VM, Kristensen VN, Kyriacou K, Lakeman IMM, Lee JW, Lee MH, Li J, Lindblom A, Lo WY, Loizidou MA, Lophatananon A, Lubiński J, MacInnis RJ, Madsen MJ, Mannermaa A, Manoochehri M, Manoukian S, Margolin S, Martinez ME, Maurer T, Mavroudis D, McLean C, Meindl A, Mensenkamp AR, Michailidou K, Miller N, Mohd Taib NA, Muir K, Mulligan AM, Nevanlinna H, Newman WG, Nordestgaard BG, Ng PS, Oosterwijk JC, Park SK, Park-Simon TW, Perez JIA, Peterlongo P, Porteous DJ, Prajzendanc K, Prokofyeva D, Radice P, Rashid MU, Rhenius V, Rookus MA, Rüdiger T, Saloustros E, Sawyer EJ, Schmutzler RK, Schneeweiss A, Schürmann P, Shah M, Sohn C, Southey MC, Surowy H, Suvanto M, Thanasitthichai S, Tomlinson I, Torres D, Truong T, Tzardi M, Valova Y, van Asperen CJ, Van Dam RM, van den Ouweland AMW, van der Kolk LE, van Veen EM, Wendt C, Williams JA, Yang XR, Yoon SY, Zamora MP, Evans DG, de la Hoya M, Simard J, Antoniou AC, Borg Å, Andrulis IL, Chang-Claude J, García-Closas M, Chenevix-Trench G, Milne RL, Pharoah PDP, Schmidt MK, Spurdle AB, Vreeswijk MPG, Benitez J, Dunning AM, Kvist A, Teo SH, Devilee P and Easton DF: Breast cancer risk genes - association analysis in more than 113,000 women. N Engl J Med 384(5): 428-439, 2021. PMID: 33471991. DOI: 10.1056/NEJMoa1913948

3 Hu C, Hart SN, Gnanaolivu R, Huang H, Lee KY, Na J, Gao C, Lilyquist J, Yadav S, Boddicker NJ, Samara R, Klebba J, 
Ambrosone CB, Anton-Culver H, Auer P, Bandera EV, Bernstein L, Bertrand KA, Burnside ES, Carter BD, Eliassen H, Gapstur SM, Gaudet M, Haiman C, Hodge JM, Hunter DJ, Jacobs EJ, John EM, Kooperberg C, Kurian AW, Le Marchand L, Lindstroem S, Lindstrom T, Ma H, Neuhausen S, Newcomb PA, O'Brien KM, Olson JE, Ong IM, Pal T, Palmer JR, Patel AV, Reid S, Rosenberg L, Sandler DP, Scott C, Tamimi R, Taylor JA, Trentham-Dietz A, Vachon CM, Weinberg C, Yao S, Ziogas A, Weitzel JN, Goldgar DE, Domchek SM, Nathanson KL, Kraft P, Polley EC and Couch FJ: A population-based study of genes previously implicated in breast cancer. N Engl J Med 384(5): 440-451, 2021. PMID: 33471974. DOI: 10.1056/NEJMoa2005936

4 LaDuca H, Stuenkel AJ, Dolinsky JS, Keiles S, Tandy S, Pesaran T, Chen E, Gau CL, Palmaer E, Shoaepour K, Shah D, Speare V, Gandomi S and Chao E: Utilization of multigene panels in hereditary cancer predisposition testing: analysis of more than 2,000 patients. Genet Med 16(11): 830-837, 2014. PMID: 24763289. DOI: $10.1038 /$ gim.2014.40

5 Walsh T, Lee MK, Casadei S, Thornton AM, Stray SM, Pennil C, Nord AS, Mandell JB, Swisher EM and King MC: Detection of inherited mutations for breast and ovarian cancer using genomic capture and massively parallel sequencing. Proc Natl Acad Sci USA 107(28): 12629-12633, 2010. PMID: 20616022. DOI: $10.1073 /$ pnas.1007983107

6 Walsh T, Casadei S, Lee MK, Pennil CC, Nord AS, Thornton AM, Roeb W, Agnew KJ, Stray SM, Wickramanayake A, Norquist B, Pennington KP, Garcia RL, King MC and Swisher EM: Mutations in 12 genes for inherited ovarian, fallopian tube, and peritoneal carcinoma identified by massively parallel sequencing. Proc Natl Acad Sci U S A 108(44): 18032-18037, 2011. PMID: 22006311. DOI: 10.1073/pnas.1115052108

7 Daly MB, Pilarski R, Yurgelun MB, Berry MP, Buys SS, Dickson P, Domchek SM, Elkhanany A, Friedman S, Garber JE, Goggins M, Hutton ML, Khan S, Klein C, Kohlmann W, Kurian AW, Laronga C, Litton JK, Mak JS, Menendez CS, Merajver SD, Norquist BS, Offit K, Pal T, Pederson HJ, Reiser G, Shannon KM, Visvanathan K, Weitzel JN, Wick MJ, Wisinski $\mathrm{KB}$, Dwyer MA and Darlow SD: NCCN guidelines insights: Genetic/familial high-risk assessment: Breast, ovarian, and pancreatic, version 1.2020. J Natl Compr Canc Netw 18(4): 380391, 2020. PMID: 32259785. DOI: 10.6004/jnccn.2020.0017

8 Tung N, Domchek SM, Stadler Z, Nathanson KL, Couch F, Garber JE, Offit K and Robson ME: Counselling framework for moderate-penetrance cancer-susceptibility mutations. Nat Rev Clin Oncol 13(9): 581-588, 2016. PMID: 27296296. DOI: 10.1038/nrclinonc .2016 .90

9 Kurian AW, Hare EE, Mills MA, Kingham KE, McPherson L, Whittemore AS, McGuire V, Ladabaum U, Kobayashi Y, Lincoln SE, Cargill M and Ford JM: Clinical evaluation of a multiplegene sequencing panel for hereditary cancer risk assessment. J Clin Oncol 32(19): 2001-2009, 2014. PMID: 24733792. DOI: 10.1200/JCO.2013.53.6607

10 Latham A, Srinivasan P, Kemel Y, Shia J, Bandlamudi C, Mandelker D, Middha S, Hechtman J, Zehir A, Dubard-Gault M, Tran C, Stewart C, Sheehan M, Penson A, DeLair D, Yaeger R, Vijai J, Mukherjee S, Galle J, Dickson MA, Janjigian Y, O’Reilly EM, Segal N, Saltz LB, Reidy-Lagunes D, Varghese AM, Bajorin D, Carlo MI, Cadoo K, Walsh MF, Weiser M, Aguilar JG, Klimstra DS, Diaz LA Jr, Baselga J, Zhang L, Ladanyi M, Hyman DM, Solit DB, Robson ME, Taylor BS, Offit
$\mathrm{K}$, Berger MF and Stadler ZK: Microsatellite instability is associated with the presence of lynch syndrome pan-cancer. J Clin Oncol 37(4): 286-295, 2019. PMID: 30376427. DOI: 10.1200/JCO.18.00283

11 Zhao P, Li L, Jiang $\mathrm{X}$ and Li Q: Mismatch repair deficiency/microsatellite instability-high as a predictor for antiPD-1/PD-L1 immunotherapy efficacy. J Hematol Oncol 12(1): 54, 2019. PMID: 31151482. DOI: 10.1186/s13045-019-0738-1

12 Whitworth J, Skytte AB, Sunde L, Lim DH, Arends MJ, Happerfield L, Frayling IM, van Minkelen R, Woodward ER, Tischkowitz MD and Maher ER: Multilocus inherited neoplasia alleles syndrome: A case series and review. JAMA Oncol 2(3): 373379, 2016. PMID: 26659639. DOI: 10.1001/jamaoncol.2015.4771

13 Spurdle AB, Greville-Heygate S, Antoniou AC, Brown M, Burke L, de la Hoya M, Domchek S, Dörk T, Firth HV, Monteiro AN, Mensenkamp A, Parsons MT, Radice P, Robson M, Tischkowitz M, Tudini E, Turnbull C, Vreeswijk MP, Walker LC, Tavtigian $\mathrm{S}$ and Eccles DM: Towards controlled terminology for reporting germline cancer susceptibility variants: an ENIGMA report. J Med Genet 56(6): 347-357, 2019. PMID: 30962250. DOI: 10.1136/jmedgenet-2018-105872

14 Tsaousis GN, Papadopoulou E, Apessos A, Agiannitopoulos K, Pepe G, Kampouri S, Diamantopoulos N, Floros T, Iosifidou R, Katopodi O, Koumarianou A, Markopoulos C, Papazisis K, Venizelos V, Xanthakis I, Xepapadakis G, Banu E, Eniu DT, Negru S, Stanculeanu DL, Ungureanu A, Ozmen V, Tansan S, Tekinel M, Yalcin S and Nasioulas G: Analysis of hereditary cancer syndromes by using a panel of genes: novel and multiple pathogenic mutations. BMC Cancer 19(1): 535, 2019. PMID: 31159747. DOI: $10.1186 / \mathrm{s} 12885-019-5756-4$

15 Daly MB, Pal T, Berry MP, Buys SS, Dickson P, Domchek SM, Elkhanany A, Friedman S, Goggins M, Hutton ML CGC, Karlan BY, Khan S, Klein C, Kohlmann W CGC, Kurian AW, Laronga C, Litton JK, Mak JS LCGC, Menendez CS, Merajver SD, Norquist BS, Offit K, Pederson HJ, Reiser G CGC, SenterJamieson L CGC, Shannon KM, Shatsky R, Visvanathan K, Weitzel JN, Wick MJ, Wisinski KB, Yurgelun MB, Darlow SD and Dwyer MA: Genetic/familial high-risk assessment: Breast, ovarian, and pancreatic, version 2.2021, NCCN clinical practice guidelines in oncology. J Natl Compr Canc Netw 19(1): 77-102, 2021. PMID: 33406487. DOI: 10.6004/jnccn.2021.0001

16 Wang J, Singh P, Yin K, Zhou J, Bao Y, Wu M, Pathak K, McKinley SK, Braun D and Hughes KS: Disease spectrum of breast cancer susceptibility genes. Front Oncol 11: 663419, 2021. PMID: 33959510. DOI: 10.3389/fonc.2021.663419

17 Braun D, Yang J, Griffin M, Parmigiani G and Hughes KS: A clinical decision support tool to predict cancer risk for commonly tested cancer-related germline mutations. J Genet Couns 27(5): 1187-1199, 2018. PMID: 29500626. DOI: 10.1007/s 10897-018-0238-4

18 Bennett RL, Steinhaus KA, Uhrich SB, O'Sullivan CK, Resta RG, Lochner-Doyle D, Markel DS, Vincent V and Hamanishi J: Recommendations for standardized human pedigree nomenclature. Pedigree Standardization Task Force of the National Society of Genetic Counselors. Am J Hum Genet 56(3): 745-752, 1995. PMID: 7887430.

19 Beitsch PD, Whitworth PW, Hughes K, Patel R, Rosen B, Compagnoni G, Baron P, Simmons R, Smith LA, Grady I, Kinney M, Coomer C, Barbosa K, Holmes DR, Brown E, Gold L, Clark P, Riley L, Lyons S, Ruiz A, Kahn S, MacDonald H, 
Curcio L, Hardwick MK, Yang S, Esplin ED and Nussbaum RL: Underdiagnosis of hereditary breast cancer: Are genetic testing guidelines a tool or an obstacle? J Clin Oncol 37(6): 453-460, 2019. PMID: 30526229. DOI: 10.1200/JCO.18.01631

20 Fostira F, Kostantopoulou I, Apostolou P, Papamentzelopoulou MS, Papadimitriou C, Faliakou E, Christodoulou C, Boukovinas I, Razis E, Tryfonopoulos D, Barbounis V, Vagena A, Vlachos IS, Kalfakakou D, Fountzilas G and Yannoukakos D: One in three highly selected Greek patients with breast cancer carries a loss-of-function variant in a cancer susceptibility gene. J Med Genet 57(1): 53-61, 2020. PMID: 31300551. DOI: 10.1136/jmedgenet-2019-106189

21 Kuchenbaecker KB, Hopper JL, Barnes DR, Phillips KA, Mooij TM, Roos-Blom MJ, Jervis S, van Leeuwen FE, Milne RL, Andrieu N, Goldgar DE, Terry MB, Rookus MA, Easton DF, Antoniou AC, BRCA1 and BRCA2 Cohort Consortium., McGuffog L, Evans DG, Barrowdale D, Frost D, Adlard J, Ong KR, Izatt L, Tischkowitz M, Eeles R, Davidson R, Hodgson S, Ellis S, Nogues C, Lasset C, Stoppa-Lyonnet D, Fricker JP, Faivre L, Berthet P, Hooning MJ, van der Kolk LE, Kets CM, Adank MA, John EM, Chung WK, Andrulis IL, Southey M, Daly MB, Buys SS, Osorio A, Engel C, Kast K, Schmutzler RK, Caldes T, Jakubowska A, Simard J, Friedlander ML, McLachlan SA, Machackova E, Foretova L, Tan YY, Singer CF, Olah E, Gerdes AM, Arver B and Olsson H: Risks of breast, ovarian, and contralateral breast cancer for BRCA1 and BRCA2 mutation carriers. JAMA 317(23): 2402-2416, 2017. PMID: 28632866. DOI: $10.1001 /$ jama.2017.7112

22 Roeb W, Higgins J and King MC: Response to DNA damage of CHEK2 missense mutations in familial breast cancer. Hum Mol Genet 21(12): 2738-2744, 2012. PMID: 22419737. DOI: $10.1093 / \mathrm{hmg} / \mathrm{dds} 101$

23 Kilpivaara O, Vahteristo P, Falck J, Syrjäkoski K, Eerola H, Easton D, Bartkova J, Lukas J, Heikkilä P, Aittomäki K, Holli K, Blomqvist C, Kallioniemi OP, Bartek J and Nevanlinna H: CHEK2 variant I157T may be associated with increased breast cancer risk. Int J Cancer 111(4): 543-547, 2004. PMID: 15239132. DOI: 10.1002/ijc.20299

24 Li J, Williams BL, Haire LF, Goldberg M, Wilker E, Durocher D, Yaffe MB, Jackson SP and Smerdon SJ: Structural and functional versatility of the FHA domain in DNA-damage signaling by the tumor suppressor kinase Chk2. Mol Cell 9(5): 1045-1054, 2002. PMID: 12049740. DOI: 10.1016/s10972765(02)00527-0

25 Falck J, Lukas C, Protopopova M, Lukas J, Selivanova G and Bartek J: Functional impact of concomitant versus alternative defects in the Chk2-p53 tumour suppressor pathway. Oncogene 20(39): 5503-5510, 2001. PMID: 11571648. DOI: 10.1038/sj.onc. 1204811

26 Falck J, Mailand N, Syljuåsen RG, Bartek J and Lukas J: The ATM-Chk2-Cdc25A checkpoint pathway guards against radioresistant DNA synthesis. Nature 410(6830): 842-847, 2001. PMID: 11298456 . DOI: $10.1038 / 35071124$

27 Thompson D, Antoniou AC, Jenkins M, Marsh A, Chen X, Wayne T, Tesoriero A, Milne R, Spurdle A, Thorstenson Y, Southey M, Giles GG, Khanna KK, Sambrook J, Oefner P, Goldgar D, Hopper JL, Easton D, Chenevix-Trench G and KConFab Investigators: Two ATM variants and breast cancer risk. Hum Mutat 25(6): 594-595, 2005. PMID: 15880680. DOI: 10.1002/humu. 9344
28 Heikkinen K, Rapakko K, Karppinen SM, Erkko H, Nieminen P and Winqvist R: Association of common ATM polymorphism with bilateral breast cancer. Int J Cancer 116(1): 69-72, 2005. PMID: 15756685. DOI: 10.1002/ijc.20996

29 Teraoka SN, Telatar M, Becker-Catania S, Liang T, Onengüt S, Tolun A, Chessa L, Sanal O, Bernatowska E, Gatti RA and Concannon P: Splicing defects in the ataxia-telangiectasia gene, ATM: underlying mutations and consequences. Am J Hum Genet 64(6): 1617-1631, 1999. PMID: 10330348. DOI: 10.1086/302418

30 Lhota F, Zemankova P, Kleiblova P, Soukupova J, Vocka M, Stranecky V, Janatova M, Hartmannova H, Hodanova K, Kmoch $\mathrm{S}$ and Kleibl Z: Hereditary truncating mutations of DNA repair and other genes in BRCA1/BRCA2/PALB2-negatively tested breast cancer patients. Clin Genet 90(4): 324-333, 2016. PMID: 26822949. DOI: $10.1111 /$ cge. 12748

31 McInerney NM, Miller N, Rowan A, Colleran G, Barclay E, Curran C, Kerin MJ, Tomlinson IP and Sawyer E: Evaluation of variants in the CHEK2, BRIP1 and PALB2 genes in an Irish breast cancer cohort. Breast Cancer Res Treat 121(1): 203-210, 2010. PMID: 19763819. DOI: 10.1007/s 10549-009-0540-9

32 Seal S, Thompson D, Renwick A, Elliott A, Kelly P, Barfoot R, Chagtai T, Jayatilake H, Ahmed M, Spanova K, North B, McGuffog L, Evans DG, Eccles D, Breast Cancer Susceptibility Collaboration (UK)., Easton DF, Stratton MR and Rahman N: Truncating mutations in the Fanconi anemia J gene BRIP1 are lowpenetrance breast cancer susceptibility alleles. Nat Genet 38(11): 1239-1241, 2006. PMID: 17033622. DOI: $10.1038 / n g 1902$

33 Levran O, Attwooll C, Henry RT, Milton KL, Neveling K, Rio P, Batish SD, Kalb R, Velleuer E, Barral S, Ott J, Petrini J, Schindler $\mathrm{D}$, Hanenberg $\mathrm{H}$ and Auerbach $\mathrm{AD}$ : The BRCA1-interacting helicase BRIP1 is deficient in Fanconi anemia. Nat Genet 37(9): 931-933, 2005. PMID: 16116424. DOI: $10.1038 / \mathrm{ng} 1624$

34 Levitus M, Waisfisz Q, Godthelp BC, de Vries Y, Hussain S, Wiegant WW, Elghalbzouri-Maghrani E, Steltenpool J, Rooimans MA, Pals G, Arwert F, Mathew CG, Zdzienicka MZ, Hiom K, De Winter JP and Joenje H: The DNA helicase BRIP1 is defective in Fanconi anemia complementation group J. Nat Genet 37(9): 934935, 2005. PMID: 16116423. DOI: 10.1038/ng1625

35 Nakamura K, Aimono E, Tanishima S, Imai M, Nagatsuma AK, Hayashi H, Yoshimura Y, Nakayama K, Kyo S and Nishihara H: Olaparib monotherapy for BRIP1-mutated high-grade serous endometrial cancer. JCO Precis Oncol 4: PO.19.00368, 2020. PMID: 32923896. DOI: 10.1200/PO.19.00368

36 de Bono J, Mateo J, Fizazi K, Saad F, Shore N, Sandhu S, Chi KN, Sartor O, Agarwal N, Olmos D, Thiery-Vuillemin A, Twardowski P, Mehra N, Goessl C, Kang J, Burgents J, Wu W, Kohlmann A, Adelman CA and Hussain M: Olaparib for metastatic castrationresistant prostate cancer. N Engl J Med 382(22): 2091-2102, 2020. PMID: 32343890. DOI: 10.1056/NEJMoa1911440

37 Stradella A, Del Valle J, Rofes P, Feliubadaló L, Grau Garces È, Velasco À, González S, Vargas G, Izquierdo Á, Campos O, Tornero E, Navarro M, Balmaña-Gelpi J, Capellá G, Pineda M, Brunet J and Lázaro C: Does multilocus inherited neoplasia alleles syndrome have severe clinical expression? J Med Genet 56(8): 521-525, 2019. PMID: 30580288. DOI: 10.1136/jmedgenet-2018-105700

38 Agiannitopoulos K, Papadopoulou E, Tsaousis GN, Pepe G, Kampouri S, Patsea E, Lypas G and Nasioulas G: Report of a germline double heterozygote in MSH2 and PALB2. Mol Genet Genomic Med 8(10): e1242, 2020. PMID: 32853479. DOI: 10.1002/mgg3.1242 
39 Kurian AW, Ward KC, Abrahamse P, Bondarenko I, Hamilton AS, Deapen D, Morrow M, Berek JS, Hofer TP and Katz SJ: Time trends in receipt of germline genetic testing and results for women diagnosed with breast cancer or ovarian cancer, 20122019. J Clin Oncol 39(15): 1631-1640, 2021. PMID: 33560870. DOI: $10.1200 / J C O .20 .02785$

40 Caswell-Jin JL, Zimmer AD, Stedden W, Kingham KE, Zhou AY and Kurian AW: Cascade genetic testing of relatives for hereditary cancer risk: Results of an online initiative. J Natl Cancer Inst 111(1): 95-98, 2019. PMID: 30239769. DOI: 10.1093/jnci/djy 147

41 Litton JK, Rugo HS, Ettl J, Hurvitz SA, Gonçalves A, Lee KH, Fehrenbacher L, Yerushalmi R, Mina LA, Martin M, Roché H, Im YH, Quek RGW, Markova D, Tudor IC, Hannah AL, Eiermann W and Blum JL: Talazoparib in patients with advanced breast cancer and a germline BRCA mutation. N Engl J Med 379(8): 753-763, 2018. PMID: 30110579. DOI: 10.1056/NEJMoa1802905

42 Robson M, Im SA, Senkus E, Xu B, Domchek SM, Masuda N, Delaloge S, Li W, Tung N, Armstrong A, Wu W, Goessl C, Runswick S and Conte P: Olaparib for metastatic breast cancer in patients with a germline BRCA mutation. N Engl J Med 377(6): 523-533, 2017. PMID: 28578601. DOI: 10.1056/NEJMoa1706450

43 Golan T, Hammel P, Reni M, Van Cutsem E, Macarulla T, Hall MJ, Park JO, Hochhauser D, Arnold D, Oh DY, ReinacherSchick A, Tortora G, Algül H, O'Reilly EM, McGuinness D, Cui KY, Schlienger K, Locker GY and Kindler HL: Maintenance olaparib for germline $B R C A$-mutated metastatic pancreatic cancer. N Engl J Med 381(4): 317-327, 2019. PMID: 31157963. DOI: 10.1056/NEJMoa1903387

44 Lin KK, Harrell MI, Oza AM, Oaknin A, Ray-Coquard I, Tinker AV, Helman E, Radke MR, Say C, Vo LT, Mann E, Isaacson JD, Maloney L, O’Malley DM, Chambers SK, Kaufmann SH, Scott CL, Konecny GE, Coleman RL, Sun JX, Giordano H, Brenton JD, Harding TC, McNeish IA and Swisher EM: $B R C A$ reversion mutations in circulating tumor DNA predict primary and acquired resistance to the PARP inhibitor rucaparib in high-grade ovarian carcinoma. Cancer Discov 9(2): 210-219, 2019. PMID: 30425037. DOI: $10.1158 / 2159-8290$.CD-18-0715

45 Coleman RL, Oza AM, Lorusso D, Aghajanian C, Oaknin A, Dean A, Colombo N, Weberpals JI, Clamp A, Scambia G, Leary A, Holloway RW, Gancedo MA, Fong PC, Goh JC, O'Malley DM, Armstrong DK, Garcia-Donas J, Swisher EM, Floquet A, Konecny GE, McNeish IA, Scott CL, Cameron T, Maloney L, Isaacson J, Goble S, Grace C, Harding TC, Raponi M, Sun J, Lin KK, Giordano H, Ledermann JA and ARIEL3 investigators: Rucaparib maintenance treatment for recurrent ovarian carcinoma after response to platinum therapy (ARIEL3): a randomised, double-blind, placebo-controlled, phase 3 trial. Lancet 390(10106): 1949-1961, 2017. PMID: 28916367. DOI: 10.1016/S0140-6736(17)32440-6

46 Oza AM, Tinker AV, Oaknin A, Shapira-Frommer R, McNeish IA, Swisher EM, Ray-Coquard I, Bell-McGuinn K, Coleman RL, O’Malley DM, Leary A, Chen LM, Provencher D, Ma L, Brenton JD, Konecny GE, Castro CM, Giordano H, Maloney L, Goble S, Lin KK, Sun J, Raponi M, Rolfe L and Kristeleit RS: Antitumor activity and safety of the PARP inhibitor rucaparib in patients with high-grade ovarian carcinoma and a germline or somatic BRCA1 or BRCA2 mutation: Integrated analysis of data from Study 10 and ARIEL2. Gynecol Oncol 147(2): 267-275, 2017. PMID: 28882436. DOI: 10.1016/j.ygyno.2017.08.022
47 Mirza MR, Monk BJ, Herrstedt J, Oza AM, Mahner S, Redondo A, Fabbro M, Ledermann JA, Lorusso D, Vergote I, Ben-Baruch NE, Marth C, Mądry R, Christensen RD, Berek JS, Dørum A, Tinker AV, du Bois A, González-Martín A, Follana P, Benigno B, Rosenberg P, Gilbert L, Rimel BJ, Buscema J, Balser JP, Agarwal S, Matulonis UA and ENGOT-OV16/NOVA Investigators: Niraparib maintenance therapy in platinumsensitive, recurrent ovarian cancer. N Engl J Med 375(22): 21542164, 2016. PMID: 27717299. DOI: 10.1056/NEJMoa1611310

48 Tutt A, Tovey H, Cheang MCU, Kernaghan S, Kilburn L, Gazinska P, Owen J, Abraham J, Barrett S, Barrett-Lee P, Brown R, Chan S, Dowsett M, Flanagan JM, Fox L, Grigoriadis A, Gutin A, Harper-Wynne C, Hatton MQ, Hoadley KA, Parikh J, Parker P, Perou CM, Roylance R, Shah V, Shaw A, Smith IE, Timms KM, Wardley AM, Wilson G, Gillett C, Lanchbury JS, Ashworth A, Rahman N, Harries M, Ellis P, Pinder SE and Bliss JM: Carboplatin in BRCA1/2-mutated and triple-negative breast cancer BRCAness subgroups: the TNT Trial. Nat Med 24(5): 628637, 2018. PMID: 29713086. DOI: 10.1038/s41591-018-0009-7

49 Gorodnova TV, Sokolenko AP, Ivantsov AO, Iyevleva AG, Suspitsin EN, Aleksakhina SN, Yanus GA, Togo AV, Maximov SY and Imyanitov EN: High response rates to neoadjuvant platinum-based therapy in ovarian cancer patients carrying germline BRCA mutation. Cancer Lett 369(2): 363-367, 2015. PMID: 26342406. DOI: 10.1016/j.canlet.2015.08.028

50 Bang YJ, Im SA, Lee KW, Cho JY, Song EK, Lee KH, Kim YH, Park JO, Chun HG, Zang DY, Fielding A, Rowbottom J, Hodgson D, O'Connor MJ, Yin X and Kim WH: Randomized, double-blind phase II trial with prospective classification by ATM protein level to evaluate the efficacy and tolerability of olaparib plus paclitaxel in patients with recurrent or metastatic gastric cancer. J Clin Oncol 33(33): 3858-3865, 2015. PMID: 26282658. DOI: $10.1200 / J C O .2014 .60 .0320$

51 Perkhofer L, Schmitt A, Romero Carrasco MC, Ihle M, Hampp S, Ruess DA, Hessmann E, Russell R, Lechel A, Azoitei N, Lin Q, Liebau S, Hohwieler M, Bohnenberger H, Lesina M, Algül H, Gieldon L, Schröck E, Gaedcke J, Wagner M, Wiesmüller L, Sipos B, Seufferlein T, Reinhardt HC, Frappart PO and Kleger A: ATM deficiency generating genomic instability sensitizes pancreatic ductal adenocarcinoma cells to therapy-induced DNA damage. Cancer Res 77(20): 5576-5590, 2017. PMID: 28790064. DOI: 10.1158/0008-5472.CAN-17-0634

52 Pennington KP, Walsh T, Harrell MI, Lee MK, Pennil CC, Rendi MH, Thornton A, Norquist BM, Casadei S, Nord AS, Agnew KJ, Pritchard CC, Scroggins S, Garcia RL, King MC and Swisher EM: Germline and somatic mutations in homologous recombination genes predict platinum response and survival in ovarian, fallopian tube, and peritoneal carcinomas. Clin Cancer Res 20(3): 764-775, 2014. PMID: 24240112. DOI: 10.1158/1078-0432.CCR-13-2287

53 Krzywinski M, Schein J, Birol I, Connors J, Gascoyne R, Horsman D, Jones SJ and Marra MA: Circos: an information aesthetic for comparative genomics. Genome Res 19(9): 16391645, 2009. PMID: 19541911. DOI: 10.1101/gr.092759.109

Received July 12, 2021

Revised October 11, 2021 Accepted October 25, 2021 